archives-ouvertes

\title{
Mobile (after-)lifeways: People at pre- and protopalatial Sissi (Crete)
}

Argyro Nafplioti, Jan Driessen, Aurore Schmitt, Isabelle Crevecoeur

\section{To cite this version:}

Argyro Nafplioti, Jan Driessen, Aurore Schmitt, Isabelle Crevecoeur. Mobile (after-)lifeways: People at pre- and protopalatial Sissi (Crete). Journal of Archaeological Science: Reports, Elsevier, 2021, 35, pp.102718. 10.1016/j.jasrep.2020.102718 . hal-03104928

\section{HAL Id: hal-03104928 \\ https://hal.archives-ouvertes.fr/hal-03104928}

Submitted on 14 Oct 2021

HAL is a multi-disciplinary open access archive for the deposit and dissemination of scientific research documents, whether they are published or not. The documents may come from teaching and research institutions in France or abroad, or from public or private research centers.
L'archive ouverte pluridisciplinaire HAL, est destinée au dépôt et à la diffusion de documents scientifiques de niveau recherche, publiés ou non, émanant des établissements d'enseignement et de recherche français ou étrangers, des laboratoires publics ou privés. 
3 Title: Mobile (after-)lifeways: People at Pre- and Protopalatial Sissi (Crete)

\section{Author names and affiliation:}

$5 \quad$ Argyro Nafplioti ${ }^{\mathrm{a}}$ (corresponding author), Jan Driessen ${ }^{\mathrm{b}}$, Aurore Schmitt ${ }^{\mathrm{c}}$, Isabelle

6 Crevecoeur $^{\mathrm{d}}$

7 a McDonald Institute for Archaeological Research, Downing Street,

8 Cambridge CB2 3ER, e-mail: argyro.nafplioti@googlemail.com

9 bUCLouvain, Aegis/CEMA/INCAL, Belgium, e-mail: jan.driessen@uclouvain.be

10 'Aix Marseille Univ, CNRS, EFS, ADES, Marseille, France, e-mail: 11 Aurore.SCHMITT@univ-amu.fr

dUMR 5199 PACEA, CNRS, Universite de Bordeaux, Pessac, France, e-mail: sabelle.crevecoeur@u-bordeaux.fr

\section{Abstract}

This paper discusses the first integrated strontium and oxygen isotope ratio results from human remains from Pre- and Protopalatial Crete, spanning the period circa 2500-1750 BCE, with a view to offering a more nuanced understanding of past populations, their diets, potential origins and aspects of their mobility: in particular, the extent to which mobility was part of these people's lives.

Twenty-six human individuals from the site of Sissi were sampled for strontium and oxygen isotope ratio in tooth enamel, while five of them were also analysed for corresponding strontium isotope signatures in bone samples. The human tooth enamel strontium isotope signatures follow a broad distribution that is in overall agreement with the diverse substrate geology reported for the site and its immediate surroundings, as well as with strontium isotope results from snail samples also collected from the broader Sissi region. In a fashion similar to the strontium data, the human oxygen isotope data point to access to different feeding territories in close proximity to the site and possibly also to variation in the composition of childhood diet, while some short-range immigration cannot be excluded either.

Isotope data variation and the inferred maximization of the exploitation of arable land to extend the agricultural resource base is largely in tune with contemporary socio-economic 
Prepalatial period. Moreover, use of multiple production zones by the people at Sissi may also be seen as a buffer against climate instability and vulnerability of coastal sites.

Based on these data we conclude that mobility was part of the life of people at Sissi. They were either moving as part of their daily routine to exploit food resources, or in relation to marital network systems some of them had moved in from nearly sites, or both the above.

Keywords: isotopes, strontium, oxygen, provenance, mobility, diet, land use, Crete.

\section{Highlights}

- First study of past human mobility on Crete using combined ${ }^{87} \mathrm{Sr} /{ }^{86} \mathrm{Sr}$ and $\delta^{18} \mathrm{O}$ evidence.

- The breastfeeding effect partly accounts for the high variation of the enamel $\delta^{18} \mathrm{O}$ data.

- Results point to access to different feeding territories close to the site.

- Data variation is consistent with land use extensification linked to settlement nucleation, population growth and possibly climate instability in this period on the island.

- Overlapping ${ }^{87} \mathrm{Sr} /{ }^{86} \mathrm{Sr}$ and $\delta^{18} \mathrm{O}$ values across the island may obscure some shortrange residential mobility linked to marital patterns. 


\section{Introduction}

Diversity in mortuary behaviour on Early Bronze Age ( $3^{\text {rd }}$ millennium BCE) Crete as amply evidenced by funerary architecture and associated material culture and osteological records has led to inferences about the possible diverse origins of the people buried (Gkalanaki, 2020; Nafplioti, 2020, 2007; Legarra Herrero, 2009; Vavouranakis 2007). The influence that the Cyclades, in particular, appear to have exercised during most of this time over the rest of the Aegean, i.e. Euboea, Eastern Attica, the north-eastern Aegean islands and further to the Aegean coast of Turkey, may also have extended to Crete (e.g. Betancourt, 2012; Day et al., 2012; Doonan and Day, 2007; Wilson et al., 2004; Papadatos, 1999; Carter, 1998; Day et al., 1998; Branigan, 1974, 1971). This has been the subject of opposing cultural diffusion and population migration interpretative models. Based on these, the transfer of material goods, ideas, practices and technologies outside the Cyclades resulted from contacts and interaction with occasional if any gene flow from the Cyclades only, as opposed to the idea that, any novelty was actually introduced by Cycladic people who moved and settled in those sites, respectively (e.g. Sampson, A. and Hadji, 2019; Papadatos, 2007; Coleman, 1988; Sampson, 1988: 126; Sapouna-Sakellarakis, 1987: 264; Doumas, 1977: 68, 1976: 77; Mylonas, 1959: 162-3; Theocharis, 1959: 300; Childe, 1957: 51-52; Papavasileiou, 1910). The case of Early Bronze Age Crete, however, probably lies somewhere in between, such that the operating networks for trade and intermarriage of the time facilitated imports and the adoption of Cycladic objects and practices by people on Crete, as well as some long-term settlement of and mixing of newcomers within the local island population/s (Broodbank, 2000).

Until 40 years ago, archaeologists largely relied on material culture alone to explore past population life-histories and used this evidence to investigate questions of provenance and mobility (e.g. Scull, 1992; Branigan, 1984; Mee, 1982; Mellart, 1975; Warren, 1973; Tringham, 1971; Caskey, 1960). Since the 1980's, however, initially in America and Northern Europe but later also in the rest of the globe, biogeochemical analysis of archaeological human skeletal remains has generated substantial new data on the lives of past people and helped shed new light onto long-standing questions of mobility, cultural discontinuity and change (e.g. Price, 2000; Ericson, 1985; van der Merwe, 1982; DeNiro and Epstein, 1981). In this paper, we use human skeletal remains from Early and Middle Bronze Age or Pre- and Protopalatial funerary contexts at Sissi on the north-east coast of Crete and employ for the first time on human remains from the island integrated oxygen and strontium isotope ratio 
analyses to offer a more nuanced understanding of past populations, their diets, potential origins and aspects of their mobility (Figure 1) (Chenery et al., 2010; Mitchell and Millard, 2009; Knudson and Price, 2007). A sample of 26 individuals was analyzed.

\section{Background}

\subsection{Archaeological context}

Excavations by a team of the UCLouvain under the auspices of the Belgian School at Athens have been taking place at the seaside promontory site of Sissi since 2007 (Driessen et al., 2018, 2012, 2011, 2009). In 10 campaigns, substantial parts of a cemetery, settlement and ceremonial building have been uncovered (Figure 2). On present evidence, the site was occupied from Early Minoan IIA (c. 2600 BCE) onwards when a village was constructed on the southeast side of the promontory. It formed, together with Malia, part of a series of villages that existed along the coast of the Malia bay that extended from Stalidha to the west to Milatos to the east. From then onwards, the site of Sissi remained occupied till the advanced Late Minoan IIIB period (c. 1230 BCE), as did Malia. This longevity of occupation can undoubtedly be explained by its advantageous strategic location. Situated on a coastal hill with relatively steep sides and beaches on either side, the site is located opposite the Selinari Gorge, then and now the only route between Central and East Crete and an ideal communication artery, allowing interregional mobility. From EM IIA onwards, the north side of the hill housed a cemetery consisting a small stone buildings and compartments, known as House Tombs in Minoan archaeology (Schmitt and Sperandio, 2018; Crevecoeur et al., 2015; Schoep et al. 2012, 2011; Crevecoeur and Schmitt, 2009). Similar tombs have been excavated at Malia, Gournia, Mochlos, Petras and Palaikastro, for example, suggesting the presence of an especially East Cretan funerary tradition (Legarra Herrero, 2014). Other regions of the island followed other traditions, which could potentially imply a different cultural background and/or origins for the different communities. Although the House Tomb cemetery may have continued in use into the advanced Neopalatial period, at least where the higher terrace (Zone 18 ) is concerned, many buildings were ruined earlier and some of these ruins were used to insert pithos burials especially during the Middle Bronze Age (e.g. Schoep et al., 2012: 3235). The bioarchaeological and chronological analyses are still ongoing. However, the published preliminary reports (Driessen et al., 2018, 2012, 2011, 2009) provide sufficient data 
to document and discuss the variability of strontium and oxygen isotope ratio values obtained from several individuals from the cemetery.

The 26 samples taken from skeletal remains for isotope analysis and presented in this paper come from burial structures that are located in various areas of the cemetery that spreads over three different terraces (Figure 3). On the lowest terrace in the east part (Zone 1), one collective burial ${ }^{1}$ and one ossuary ${ }^{2}$ (Crevecoeur et al., 2015), Burial Buildings 1.9 and 1.10, were excavated, comprising respectively at least 11 and 20 individuals (Schoep et al., 2011: 64-66). From here come the five samples SAN 2 to 6. Further east, on a slightly higher first terrace, is a series of north-facing funerary buildings. While the plans of the spaces are relatively clear, there was not much earth deposition and erosion had taken its toll. Still, in some cases skeletal remains were sufficiently well preserved for sampling. From the higher, only partially excavated levels in spaces $1.30-31$, a waste area resulting probably from tombs emptied, come samples SAN 12 and 13, while from the largest room, a collective burial1.7, four samples were taken (SAN 14 to 17). On the second terrace, more to the west, one sample was taken in compartment 1.2 from Burial Building 1.1-1.3 (SAN 1). On the third and upper terrace, samples were taken both in the east part (Zone 1) and in the north zone of the cemetery (Zone 9), which is about $35 \mathrm{~m}$ to the west. In this north zone, there is a large Middle Minoan I-II Burial Building A (Schmitt and Sperandio, 2018) and from the first two excavated rooms 9.1-9.2, five samples (SAN 7 to 11) were taken. The west part of the east cemetery on the third terrace comprised a series of small stone compartments. The narrowness of the compartments and their bad preservation makes it difficult to discern a clear plan in the remains but from skeletal remains in one space (1.20) sample SAN 21 was taken. From skeletal remains in the corridor-like structure east (1.18) two more samples were taken (SAN 25-26). The eastern part of this terrace has at its core an EM IIB Burial Building with two compartments (1.11 and 1.12). Each room was sampled (SAN 18-24). This EM IIB tomb was partly overbuilt later and from this later room (space 1.17) we took two more samples (SAN 22-23). Two more samples were taken from a context (space 1.29) that is even at a higher level and probably even later (SAN 19-20). The plan in figure 3 shows that large parts of the cemetery were covered by this sampling, which can be considered as representative. Moreover, samples date from in between EM IIB to MM IIB (ca. 2500-1750 $\mathrm{BCE}$ ), and may hence also provide a chronological representativity. Table 1 provides information on burial practices (individual or commingled remains) and the type of samples.

\footnotetext{
${ }^{1}$ Successive burials through time in a single space

${ }^{2}$ Secondary deposit of incomplete individuals which is related to a ritualised management of space; it is a post-funerary practice.
} 


\subsection{Strontium and oxygen isotope ratio analysis: principles}

154

155

156

157

158

159

160

161

162

163

164

165

166

167

168

169

170

171

172

173

174

175

176

177

178

179

180

181

182

Strontium and oxygen form two independent isotopic systems, which reflect local geology and climate respectively. As oxygen and strontium isotopes in teeth are fixed in enamel biogenic apatite at the time of tooth formation and enamel undergoes little remodelling thereafter, the isotope ratio values recorded reflect childhood provenance and provide complementary evidence for geographical origins and mobility (Hoppe et al., 2003; Hillson, 2002; Price et al., 2002, White et al., 1998).

\subsubsection{Strontium isotope ratio $\left({ }^{87} \mathrm{Sr} /{ }^{86} \mathrm{Sr}\right)$ analysis}

Strontium isotope ratios of human skeletal tissues are largely used as a proxy for local geology in order to determine the geographical origins of the individuals examined and distinguish between locals and non-locals. Since the principles of ${ }^{87} \mathrm{Sr} /{ }^{86} \mathrm{Sr}$ analysis in research of this kind are well documented (Evans et al., 2009; Bentley, 2006; Price et al. 2002), and have also been extensively discussed in earlier relevant work of one of the authors (e.g. Nafplioti, 2012a, 2011, 2008), the following is only a summary.

In nature, strontium occurs in the form of four stable isotopes, ${ }^{87} \mathrm{Sr}$ (comprises c. $7.04 \%$ of total strontium), ${ }^{88} \mathrm{Sr}$ (c. $82.53 \%$ ), ${ }^{86} \mathrm{Sr}$ (c. 9.87\%) and ${ }^{84} \mathrm{Sr}$ (c. $0.56 \%$ ). Strontium isotope ${ }^{87} \mathrm{Sr}$ is radiogenic and is the product of the radioactive decay of the rubidium isotope ${ }^{87} \mathrm{Rb}$, which has a half-life of approximately 47 billion years. All other three strontium isotopes are non-radiogenic (Faure, 1986). Therefore, in any geology the ratio of strontium isotope ${ }^{87} \mathrm{Sr}$ to ${ }^{86} \mathrm{Sr}$ depends on the relative abundance of rubidium and strontium at the time the rock crystallised and the age of the rocks (Rogers and Hawkesworth, 1989). Because rubidium is much more abundant in crustal materials than in the Earth's mantle, old metamorphic rocks of crustal origin have higher ${ }^{87} \mathrm{Sr} /{ }^{86} \mathrm{Sr}$ values (c. 0.715) than recent volcanic rocks (c. 0.704) (Wright 2005). Strontium isotope ratios in marine sedimentary rocks depend on the ${ }^{87} \mathrm{Sr} /{ }^{86} \mathrm{Sr}$ value of seawater at the time they were formed and largely vary between 0.707 and 0.710 (Palmer and Elderfield, 1985; Elderfield, 1986)

In essence, ${ }^{87} \mathrm{Sr} /{ }^{86} \mathrm{Sr}$ largely reflects local geology, and passes from the bedrock into the soil, the groundwater and the food chain. Thereby ${ }^{87} \mathrm{Sr} /{ }^{86} \mathrm{Sr}$ reaches the human skeletal tissues, where it substitutes for calcium in hydroxyapatite (Faure 1986), largely from the food 
and water consumed with no fractionation related to biological processes (Blum et al., 2000; Graustein, 1989). Although other factors such as proximity to marine environments and ${ }^{87} \mathrm{Sr} /{ }^{86} \mathrm{Sr}$ in sea spray (Veizer, 1989), atmospheric deposition (Miller et al., 1993) and in modern contexts fertilizers too, can also impact on local ${ }^{87} \mathrm{Sr} /{ }^{86} \mathrm{Sr}$ signatures, the latter largely reflect bedrock geology and mineral weathering (Bentley, 2006.). Thus ${ }^{87} \mathrm{Sr} /{ }^{86} \mathrm{Sr}$ signatures in human skeletal tissues match the geochemical profile of the catchment area of the individuals analysed.

Because tooth enamel is a cell-free tissue that for most of the permanent dentition largely forms by the $8^{\text {th }}$ year of life and does not remodel thereafter (Hillson, 2002:148; Ubelaker, 1989), ${ }^{87} \mathrm{Sr} /{ }^{86} \mathrm{Sr}$ signatures from tooth enamel reflect early childhood diet and geographical origins. Conversely, bone and, to a lesser extent, also dentine, undergo continuous replacement of their mineral phase in the course of life. Thus cortical bone ${ }^{87} \mathrm{Sr} /{ }^{86} \mathrm{Sr}$ signatures more closely reflect the dietary intake of the last 10 years of life, and human bone ${ }^{87} \mathrm{Sr} /{ }^{86} \mathrm{Sr}$ values can be used to characterize local bioavailable ${ }^{87} \mathrm{Sr} /{ }^{86} \mathrm{Sr}$ at one's site of residence prior to death (Nafplioti, 2008; Tafuri et al., 2006; Ezzo and Price, 2002; Ezzo et al., 1997; Grupe et al., 1997; Price et al., 1994).

Acknowledging the possibility of recent immigrants amongst the individuals tested, samples from archaeological and/or modern animal skeletal tissues offer a more reliable measure of the local bioavailable ${ }^{87} \mathrm{Sr} /{ }^{86} \mathrm{Sr}$. They provide an average of the bioavailable ${ }^{87} \mathrm{Sr} /{ }^{86} \mathrm{Sr}$ signatures of the feeding territories that these animals occupied in life and are thereby widely accepted as an accurate measure of the range of local ${ }^{87} \mathrm{Sr} /{ }^{86} \mathrm{Sr}$ values in soils, plants, animals and waters in the areas investigated (e.g. Nafplioti, 2012a; Wright, 2005; Bentley et al. 2004; Price et al., 2002). Therefore, in principle, if an individual was born and raised in the local area, the ${ }^{87} \mathrm{Sr} /{ }^{86} \mathrm{Sr}$ values measured from his/her tooth enamel should be similar to his/her bone ${ }^{87} \mathrm{Sr} /{ }^{86} \mathrm{Sr}$ and the local bioavailable ${ }^{87} \mathrm{Sr} /{ }^{86} \mathrm{Sr}$ signatures. They will also be in overall agreement to comparable data from local geological material(s). Otherwise, if tooth enamel ${ }^{87} \mathrm{Sr} /{ }^{86} \mathrm{Sr}$ signatures are found to be significantly different from the local ${ }^{87} \mathrm{Sr} /{ }^{86} \mathrm{Sr}$, we may infer that the respective people spent their childhood at (a) location(s) geologically and isotopically different from their residence prior to death. 


\subsubsection{Oxygen isotope ratio $\left({ }^{18} \mathrm{O} /{ }^{16} \mathrm{O}\right)$ analysis}

It is well-established that the oxygen isotope ratio $\left({ }^{18} \mathrm{O} /{ }^{16} \mathrm{O}\right)$ of precipitation reflects the regional climatic conditions (i.e. temperature, humidity, distance from the sea and elevation) and decreases with distance from the sea, altitude, and falling temperature (Bowen and Revenaugh, 2003; Faure, 1986; Gat, 1980). Also, ${ }^{18} \mathrm{O} /{ }^{16} \mathrm{O}$ values are negatively correlated with humidity levels (Darling et al., 1996; Yurtsever and Gat ,1981).

Oxygen isotopes in the body of humans and other mammals are subject to several stages of metabolic fractionation from imbibed water, which is related to local precipitation (Longinelli, 1984; Luz et al., 1984), to body fluids and from the latter to skeletal apatite. This fractionation is now adequately understood and predictable, so that approximate ${ }^{18} \mathrm{O} /{ }^{16} \mathrm{O}$ values for the imbibed meteoric water can be calculated and used to characterise the regional ecological context and probable geographic origins for the individuals analysed. Despite the difference between the oxygen isotope composition of the structural carbonate and phosphate components of bone or enamel apatite, oxygen of both the structural carbonate and phosphate of biogenic apatite has been demonstrated for modern mammals to be in equilibrium with body water (Daux et al., 2008; Iacumin et al., 1996; Kohn et al., 1996; D’Angela and Longinelli, 1990; Levinson et al., 1987; Longinelli, 1984). Also, there is a known quantitative relationship between the oxygen isotopic compositions of the two components of skeletal apatite (Bryant et al., 1996; Iacumin et al., 1996).

Tooth enamel ${ }^{18} \mathrm{O} /{ }^{16} \mathrm{O}$ largely reflects the ${ }^{18} \mathrm{O} /{ }^{16} \mathrm{O}$ in drinking water and also water in foods consumed by the individual during childhood, when teeth are formed (Hillson 2002), with some enrichment in ${ }^{18} \mathrm{O}$ owing to metabolic fractionation. Moreover, tooth enamel ${ }^{18} \mathrm{O} /{ }^{16} \mathrm{O}$ values from teeth formed during the first few years of life, i.e. the incisors, canine and $1^{\text {st }}$ molar, when the individuals were most probably (still) breastfeeding, are enriched in ${ }^{18} \mathrm{O}$ $\left({ }^{18} \mathrm{O} /{ }^{16} \mathrm{O}\right.$ values raised by ca. $1 \%$ ) compared to teeth that form following cessation of the breastfeeding, reflecting a trophic level effect (Wright and Schwarcz, 1998).

Determination of the local biologically available ${ }^{18} \mathrm{O} /{ }^{16} \mathrm{O}$ is not as straightforward as for ${ }^{87} \mathrm{Sr} /{ }^{86} \mathrm{Sr}$ above, owing to the difficulty in determining the various water sources used by the population tested and the possibility that exact values for prehistoric ${ }^{18} \mathrm{O} /{ }^{16} \mathrm{O}$ and their patterning were different from ${ }^{18} \mathrm{O} /{ }^{16} \mathrm{O}$ in modern precipitation. Additional complications come from inter-species variation in ${ }^{18} \mathrm{O} /{ }^{16} \mathrm{O}$ values largely linked to physiology and dietary differences (Bentley and Knipper, 2005; White et al., 2004; Kohn, 1996).

Moreover, owing to much overlap in human ${ }^{18} \mathrm{O} /{ }^{16} \mathrm{O}$ values from different locations across continents, identifying probable geographical origins on the basis of oxygen isotope 
analysis alone often is not possible (Lightfoot and O'Connell, 2016). Instead, the efficiency of oxygen isotopes for tracing the provenance of human skeletal remains is reinforced when combined with strontium and/or other isotope ratios such as isotopes of lead or sulphur, which serve as proxies for local geology rather than local environment (Redfern et al., 2016; Muldner et al., 2011; Turner et al., 2009).

\subsection{Geological context}

The island of Crete largely falls within the Gavrovo isotopic/tectonic zone, while its basement comprises nappes that represent rocks of several different environments, stacked up on top of each other during the Alpine compression (Higgins and Higgins, 1996: 197). The Gavrovo zone was a continental fragment for the early part of its history, where the Mesozoic shallow-water limestones were later almost completely covered up by late Eocene flysch sediments (Higgins and Higgins, 1996: 19).

The archaeological site of Sissi on the north-east coast of the island is set on a narrow strip of alluvium. Less than $1 \mathrm{~km}$ to its south and further west extend Jurassic to Eocene thick bedded to massive limestones and dolomites of tidal to shallow water origin. For a small part to its south, these rocks are interrupted by an outcrop of the "Phyllite -Quartzite series" that contains rocks of different age, origin and grade of metamorphism. These include PermoTriassic shales, phyllites, quartzphyllites and quartzites. Upper Miocene to Lower Pliocene limestones extend immediately to the east of the site, while no more than $5 \mathrm{~km}$ further in the same direction occur older rocks, i.e. Jurassic to Eocene crystalline limestones with bands and nodules of chert (Creutzburg, 1977). The site of Sissi and its immediate periphery are thus characterized by high geological variability.

\section{Materials and Methods}

\subsection{Samples}

Strontium and oxygen isotope ratios were measured from tooth enamel samples from twenty-six individuals from different chronological contexts and locations within the Sissi cemetery chosen to span the entire site. Five of them were also analysed for corresponding ${ }^{87} \mathrm{Sr} /{ }^{86} \mathrm{Sr}$ signatures in bone samples. The latter, including isotope ratio values from four snail 
shell samples from the archaeological site of Sissi and the nearby village of Vrachasi, situated approximately $6 \mathrm{~km}$ to its south, which were used to characterize local bioavailable ${ }^{87} \mathrm{Sr} /{ }^{86} \mathrm{Sr}$, are reported in Table 1.

All human teeth sampled had previously been studied macroscopically. The majority had been recovered as loose teeth ( 2 of the 26 teeth only were found attached to the associated maxillary/mandibular bone); hence it was not possible to confidently determine whether they belonged to male or female individuals or their precise age-at-death except for a few individuals only; all relevant information is included in Table 1.

For the purposes of ${ }^{18} \mathrm{O} /{ }^{16} \mathrm{O}$ analysis, we aimed for the second permanent molar (M2), because the M2 enamel is known to form largely between the age of seven and eight (Scheuer and Black, 2000; Ubelaker, 1989) and therefore the measured ${ }^{18} \mathrm{O} /{ }^{16} \mathrm{O}$ signatures are not expected to be affected by the consumption of mother's milk (Jay et al. 2008; Hoppe et al., 2003; Hillson, 2002; Montgomery, 2002; White et al., 2000; Wright and Schwarcz, 1998). This is known as the 'breastfeeding effect' where the oxygen isotope signal of enamel that mineralised during breastfeeding is raised by up to $1 \%$ over that of later forming teeth, reflecting the fact that nursing infants are feeding at a higher trophic level than their mothers. Where the M2, however, could not be sampled, it was substituted by the first molar (M1), an earlier forming tooth, and this will be taken into account in the discussion and interpretation of the results.

\section{2 Sample preparation and analysis}

\section{2.1 Strontium isotope ratio analysis}

The analytical protocol for ${ }^{87} \mathrm{Sr} /{ }^{86} \mathrm{Sr}$ analysis, including procedures of sample extraction and sample preparation prior to analysis, have been described in earlier publications (Nafplioti 2008, 2009, 2011). Preparation and analysis of the samples were carried out at the National Oceanography Centre in Southampton, where the actual ${ }^{87} \mathrm{Sr} /{ }^{86} \mathrm{Sr}$ values were measured to the sixth decimal digit by a ThermoFisher TRITON Plus Thermal Ionization Mass Spectrometer (7 Collectors). 
3.2.2. Oxygen isotope ratio analysis

${ }^{18} \mathrm{O} /{ }^{16} \mathrm{O}$ was measured in the structural carbonate component of enamel apatite, because it is an easier, faster and less expensive method than measuring this in phosphate apatite, while it simultaneously recovers ${ }^{13} \mathrm{C} /{ }^{12} \mathrm{C}$ values as well (Bryant et al. 1996; Bentley and Knipper 2005). Moreover, the isotope compositions of oxygen in the structural carbonate and phosphate components of bone or enamel apatite are related in a quantitative manner and ${ }^{18} \mathrm{O} /{ }^{16} \mathrm{O}$ carbonate values can easily be converted to the corresponding ${ }^{18} \mathrm{O} /{ }^{16} \mathrm{O}$ phosphate values (see Bryant et al., 1996; Iacumin et al., 1996a).

Following abrasion of the external tooth crown enamel surface using a dremel tool, enamel powder of approximately 8-12 $\mu \mathrm{g}$ was drilled out from the entire crown height avoiding to sample any adhering dentine. Enamel powders were then treated for bioapatite extraction following Balasse and colleagues (2002). After soaking samples in sodium hypochlorite $2-3 \%\left(24 \mathrm{~h}\right.$ at $\left.4^{\circ} \mathrm{C}\right)$ to remove organic matter, the samples were rinsed five times in distilled water and mixed with $0.1 \mathrm{M}$ acetic acid $(0.1 \mathrm{ml} / \mathrm{mg})$ for four hours at room temperature to remove exogenous carbonate. Following five rinses the samples were placed in the freezer at $-20^{\circ} \mathrm{C}$ for 1 hour, and then at $-80^{\circ} \mathrm{C}$ for an additional 30 minutes before being freeze dried for 90 minutes. The dried samples were then transferred into suitable tubes and placed into a VG SIRA mass spectrometer, where each sample was reacted with $100 \%$ ortho phosphoric acid at $70 \mathrm{oC}$. Liberated $\mathrm{CO} 2$ was then trapped and transferred to the mass spectrometer for the isotopic analysis. Results are reported with reference to the international standard VPDB calibrated through the NBS19 standard (Hoefs, 1997; Coplen, 1995) in standard delta $(\delta)$ notation relative to the VPDB international standard and are expressed in units per mil (\%o), i.e. $\delta^{18} \mathrm{O}=1000 \times\left[\left({ }^{18} \mathrm{O} /{ }^{16} \mathrm{O}\right.\right.$ sample $) /\left({ }^{18} \mathrm{O} /{ }^{16} \mathrm{OVPDB}\right)-1$, (Table 1$)$.

All oxygen isotope ratio measurements including sample preparation were carried out at the McDonald Institute for Archaeological Research, University of Cambridge. The long term analytical precision is better than $\pm 0.08 \%$ ofor ${ }^{13} \mathrm{C} /{ }^{12} \mathrm{C}$ and better than $\pm 0.10 \%$ for ${ }^{18} \mathrm{O} /{ }^{16} \mathrm{O}$.

\section{Results}

Strontium and oxygen isotope ratio results from the 26 individuals from Sissi analysed are displayed in Table 1 and Figs. 4 and 8. 
The human tooth enamel strontium isotope ratios range between 0.70860 and 0.70971 (mean: $0.70939,0.000482 \sigma$ ) (Table 1, Figures 4, 7 and 8). Variation is high, evidenced by the large standard deviation and range (Table 2). It is higher than other Bronze Age human skeletal collections in the South Aegean, viz. the Grave Circle A at Mycenae $(\sigma=0.00002)$, the Ailias $(\sigma=0.00010)$, Gypsades $(\sigma=0.00003)$, and Sellopoulo $(\sigma=0.00015)$ collections from Knossos, but lower compared with Manika on Euboea $(\sigma=0.00065)$, the Chora of Naxos $(\sigma=0.00044)$ and Knossos South of the Palace $(\sigma=0.00025)$ (Nafplioti 2007, 2008, 2009a, 2009b, 2012b).

Strontium isotope signatures from snails collected from the excavation site (1) and the neighbouring village of Vrahasi (3) range between 0.70783 and 0.70974 . Variation for the snail isotope values (mean: $0.70863,0.001762 \sigma$ ) is higher compared to the human tooth enamel signatures. By contrast, the human bone strontium isotope signatures from the site are more homogeneous and range from 0.70928 to 0.70944 (mean: $0.709301,0.000162 \sigma$ ).

Oxygen isotope ratios from tooth enamel carbonate from the same individuals yielded $\delta^{18} \mathrm{O}_{\mathrm{c}}$ values which are reported relative to the VPDB international standard. In order to facilitate comparison of the human $\delta^{18} \mathrm{O}_{\mathrm{c}}$ values to local precipitation data from the region and further explore provenance for the respective individuals we converted the carbonate oxygen VPDB data to carbonate oxygen VSMOW values using the equation below (1)

$\delta^{18}$ O VSMOW $=(1.0309 \times \delta 18 \mathrm{OVPDB})+30.9$ (1) (Friedman and O'Neil1977; Henton, et al. 2010, 439)

and calculated the corresponding $\delta^{18} \mathrm{O}$ values for drinking water $\left(\delta^{18} \mathrm{O}_{\mathrm{dw}}\right)$. Converting the human phosphate $\delta^{18} \mathrm{O}$ to $\delta^{18} \mathrm{O}$ water signatures allows comparability to data from modern precipitation and outweighs any concerns with the choice of appropriate published equation or with error propagation (Pryor et al., 2014; Chenery et al., 2012; Pollard et al., 2011; Chenery et al., 2010; Daux et al., 2008; Levinson et al., 1987; Luz and Kolodny, 1985; Longinelli, 1984). To this end we used the equation formulated by Daux et al. (2008) modified following Iacumin and colleagues (1996) to reflect the correlation between $\delta^{18} \mathrm{O}$ values measured in the structural carbonate and phosphate components of apatite, respectively, as follows $(2,3)$ :

$$
\text { If } \delta^{18} \mathrm{O}_{\mathrm{mw}}=1.54( \pm 0.09) \times \delta^{18} \mathrm{O}_{\mathrm{p}}-33.72( \pm 1.51) \quad \text { (2) Daux et al. (2008) }
$$

and 
Then

$\delta^{18} \mathrm{O}_{\mathrm{mw}}=1.51 \times \delta^{18} \mathrm{O}_{\mathrm{c}}-46.81$

The results of the above calculations are given in Table 1.

As was observed from the ${ }^{87} \mathrm{Sr} /{ }^{86} \mathrm{Sr}$ human tooth enamel data, the $\delta^{18} \mathrm{Op}$ values from the same individuals follow a rather broad distribution, from $17.3 \%$ to $19.9 \%$ (mean $18.7 \pm 1.2 \%$, $2 \sigma$ ) with corresponding drinking water values between $-7.3 \%$ and $-3.4 \%$ (mean $-5.3 \pm 1.7 \%$, $2 \sigma$ ) (Table 1, Figure 4).

\section{Discussion}

\subsection{Variation in strontium isotope ratios}

Provided that the substrate local geology within the catchment area is rather homogeneous, human tooth enamel ${ }^{87} \mathrm{Sr} /{ }^{86} \mathrm{Sr}$ signatures at any given site are expected to be normally distributed for people who were born and raised locally, subsisted on more or less the same locally-grown or locally-procured foods, i.e. there was no differential access to food resources of any kind, and were not appreciably mobile (Wright 2005). Descriptive statistics applied to the Sissi human tooth enamel ${ }^{87} \mathrm{Sr} /{ }^{86} \mathrm{Sr}$ data suggest a significant deviation from a normal distribution (Shapiro-Wilk Test: $\mathrm{p}=0.019$ ) (Table 2). Distribution of the ${ }^{87} \mathrm{Sr} /{ }^{86} \mathrm{Sr}$ signatures is leptokurtic, i.e. it has a positive kurtosis, and it is also skewed towards values higher than the mean, resulting in a median that is higher than the mean. The above are illustrated in Figure 5, where an estimated normal distribution curve is also plotted for comparative purposes. The enamel ${ }^{87} \mathrm{Sr} /{ }^{86} \mathrm{Sr}$ value of 0.70860 (SAN7) lays more than $2 \sigma$ away from the mean ${ }^{87} \mathrm{Sr} /{ }^{86} \mathrm{Sr}$ of the Sissi assemblage, and thus stands out at the left tail of the distribution curve as a possible outlier, i.e. a non-local at Sissi. When this outlier is eliminated from the dataset, the now trimmed data appear to follow a normal distribution (Shapiro-Wilk Test: $p=0.739)$; intra-group variation is lower $(\sigma=0.00018)$ compared to the complete data set; mean (0.70942) and median (0.70945) are closer (Table 2, Figure 6).

Albeit not statistically justified, additional values at the tails of the distribution may also indicate non-locals at Sissi, or people who moved at Sissi when they were very young, i.e. while tooth enamel for the permanent dentition was still forming (Figure 6). Nonetheless, 
403

404

405

406

407

408

409

410

411

412

413

414

415

416

417

418

419

420

421

422

423

424

425

426

427

428

429

430

431

432

433

434

435

436

it is not clear where exactly in the distribution one should safely draw the boundaries for the local Sissi population. Data on the local biologically available ${ }^{87} \mathrm{Sr} /{ }^{86} \mathrm{Sr}$ on the one hand, and information on the local geology and the site's distance from the sea on the other, may therefore prove useful in this respect.

Figure 7 plots the human tooth enamel and bone ${ }^{87} \mathrm{Sr} /{ }^{86} \mathrm{Sr}$ signatures together with data on the local biologically available ${ }^{87} \mathrm{Sr} /{ }^{86} \mathrm{Sr}$ measured from snail shells from the site and the broader region. The human cortical bone values reflect adult diet during the last 10-15 years or so in one's life and follow a narrower distribution than the tooth enamel ratios. This is not surprising as tooth enamel ratios reflect a much narrower period, i.e. a maximum of 2 to 3 years in early childhood. Additionally, bone is more susceptible to post-depositional contamination, which would potentially narrow isotope ratio variation down to the isotope ratio signatures of the burial environment. Bone isotope signatures are also less variable than the ratios measured from the snail shells.

Snail shell ${ }^{87} \mathrm{Sr} /{ }^{86} \mathrm{Sr}$ values are in good agreement with the highly variegated substrate geology for the broader Sissi region where limestones of different age and old metamorphic rocks occur in a radius of just $5 \mathrm{~km}$, as described in Section (2.3) above. Intra-group variation $(\sigma=0.00088)$ for the four snail samples is higher compared to the human enamel values, while the actual values range between 0.70783 and 0.70974 . The latter was measured from a specimen collected from the excavation site, while the remainder three ${ }^{87} \mathrm{Sr} /{ }^{86} \mathrm{Sr}$ shell values average at $0.70830 \pm 0.00062$ and were measured from the three Vrachasi village snails. All 26 human enamel ratios in fact fall within the range of the snail ratios and can therefore be identified as locals within the broader region of Sissi (Figures 4 and 8).

If we look carefully at the Sissi human enamel ${ }^{87} \mathrm{Sr} /{ }^{86} \mathrm{Sr}$ data, these generally fit provenance in coastal areas where marine strontium from seaspray, rainwater and shell sands have a significant impact on the local biosphere $\mathrm{Sr}$ values, i.e. around 0.7090-0.7092 (Montgomery et al., 2007; Bentley, 2006: 153; Montgomery et al., 2003; Veizer, 1989). Nonetheless, the ${ }^{87} \mathrm{Sr} /{ }^{86} \mathrm{Sr}$ value from individual SAN7, who was statistically identified as an outlier, falls below the modern seawater ${ }^{87} \mathrm{Sr} /{ }^{86} \mathrm{Sr}$ constant of 0.7092 (Veizer 1989). Albeit not compatible with an origin from a coastal site, the ${ }^{87} \mathrm{Sr} /{ }^{86} \mathrm{Sr}$ value from SAN7 does not exclude an origin within the island. Strontium isotope ratios similar to SAN7 from Burial Building 9.1, although rare amongst the local bioavailable ${ }^{87} \mathrm{Sr} /{ }^{86} \mathrm{Sr}$ signatures from Crete, are not altogether absent. In fact, the two lowest ${ }^{87} \mathrm{Sr} /{ }^{86} \mathrm{Sr}$ signatures from the Vrachasi snails measured as 0.70783 and 0.70807 suggest that it would not be illegitimate to infer that SAN7 was local at the broader Sissi region. Similarly low isotope values from the rest of the island, 
including a published value of 0.70853 measured from a sheep/goat from Bronze Age Knossos (Nafplioti 2011: 1564, 1567), as well as more data currently under preparation for publication (Nafplioti, in preparation) further corroborate a provenance within the island for the individuals in question.

The remainder of the Sissi human enamel ${ }^{87} \mathrm{Sr} /{ }^{86} \mathrm{Sr}$ values range between 0.70903 and 0.70971 and average at $0.70942 \pm 0.00018$. More than half of these values fall within the range of the mean human bone ${ }^{87} \mathrm{Sr} /{ }^{86} \mathrm{Sr} \pm 2 \sigma(0.70915$ to 0.70946$)$ and can thus be identified as locals at Sissi. Moreover, based on the ${ }^{87} \mathrm{Sr} /{ }^{86} \mathrm{Sr}$ signature from the snail from the archaeological site (0.70974), the more radiogenic human enamel values, i.e. those between 0.7096 and 0.7097 , can also be identified as locals at the site.

In the context of high variation in the underlying geology of the region, the more radiogenic enamel ${ }^{87} \mathrm{Sr} /{ }^{86} \mathrm{Sr}$ signatures probably reflect older geological formations and different catchment areas for the respective individuals compared to burials with lower ${ }^{87} \mathrm{Sr} /{ }^{86} \mathrm{Sr}$ signatures that are close to the seawater ${ }^{87} \mathrm{Sr} /{ }^{86} \mathrm{Sr}$ constant. The human enamel ${ }^{87} \mathrm{Sr} r{ }^{86} \mathrm{Sr}$ results therefore point to extensification of land use in this period and access to different feeding territories in close proximity to the site (e.g. Haggis, 1999: 64; Manning, 1994: 234), for instance within a radius of a couple of kilometers. The use of multiple production zones by the Sissi people can also be seen as a buffer against climate instability and vulnerability of coastal sites (Moody, 2012: 259-64). To some extent variation in human enamel ${ }^{87} \mathrm{Sr} /{ }^{86} \mathrm{Sr}$ values, may also reflect variation in the composition of people's childhood diet in terms of proportions of foodstuffs of higher and lower strontium concentration and of different associated ${ }^{87} \mathrm{Sr} /{ }^{86} \mathrm{Sr}$ signatures: for instance meat and milk that contain less strontium compared to plant foods will have a rather small impact on the average human skeletal strontium isotope signatures compared to that of the strontium-rich plants consumed by the respective people (Montgomery and Evans, 2009: 125). Alternatively, some of the Sissi individuals may have been born and raised in nearby sites, so that the observed high human enamel ${ }^{87} \mathrm{Sr} /{ }^{86} \mathrm{Sr}$ variation may also reflect small-scale, short-range intra-island residential mobility. This probability, however, cannot be adequately assessed using strontium data alone due to overlapping bioavailable strontium isotope signatures across parts of the island linked to similarities in the underlying geology (Nafplioti, 2011, 2015). Nor can we test for any sexpattern in data variation and whether marital patterns may (partly) account for any intra-island residential mobility (as demonstrated in Bentley et al., 2005), owing to the small number of Sissi individuals, who could be confidently sexed. 
5.2 Variation in oxygen isotope ratio values

The human enamel $\delta^{18} \mathrm{O}_{\mathrm{p}}$ signatures on Figure 4 follow a rather broad data distribution (17.3\%o to $20.0 \%$ (mean $18.7 \pm 1.2 \%$, $2 \sigma$ ). To a great extent this probably also reflects the breastfeeding effect and the enrichment of $\delta^{18} \mathrm{O}_{\mathrm{p}}$ values from the M1s analysed. If we correct for this effect by subtracting $1 \%$ from the $\mathrm{M} 1 \delta^{18} \mathrm{Op}$ values, the $\delta^{18} \mathrm{O}_{\mathrm{p}}$ range narrows down to between $16.9 \%$ and $19.0 \%$ (mean $17.8 \pm 1 \%$, $2 \sigma$ ) with corresponding drinking water values between $-7.9 \%$ and $-4.9 \%$ (mean $-6.4 \pm 1.7 \%$, $2 \sigma$ ) (Table 1, Figure 8 ).

Due to the lack of empirical data on the range of oxygen isotope ratio variation for the local Sissi population, as we have for other sites where the local ${ }^{87} \mathrm{Sr} /{ }^{86} \mathrm{Sr}$ signatures could be used to determine corresponding local $\delta^{18} \mathrm{O}_{\mathrm{p}}$ values (e.g. Hughes et al 2014; Eckardt et al., 2009), we were not able to determine local $\delta^{18} \mathrm{O}_{\mathrm{p}}$ ranges for humans in this context. Instead we used published $\delta^{18} \mathrm{O}$ data on modern precipitation (Lykoudis and Argyriou, 2007) to extrapolate what might be acceptable drinking water $\delta^{18} \mathrm{O}$ values for the Bronze Age inhabitants of Sissi. These data suggest that modern $\delta^{18} \mathrm{Omw}$ values across Crete range between -5 and $-7 \%$ with the more positive values occurring on the coastal areas and the more negative towards the interior of the island. These data thus are in good overall agreement with the $\delta^{18} \mathrm{O}_{\mathrm{dw}}$ values measured from the Sissi individuals and with provenance within the island that had also been suggested based on the corresponding strontium isotope data.

Due to overlapping strontium and oxygen isotope signatures between the central Cyclades and the site of Sissi, the results cannot be used to test a Cycladic presence at the site. The resolution of modern precipitation $\delta^{18} \mathrm{O}$ data from Crete and the south Aegean (Lykoudis and Argyriou, 2007) is unfortunately not high enough to clearly separate between sites on Crete and the Cyclades. On Crete, however, the data rather show general differences depending on proximity to the sea and/or altitude for sites/parts of the island. In this respect, the human $\delta^{18} \mathrm{O}_{\mathrm{dw}}$ signatures appear to reflect the variation of modern precipitation $\delta^{18} \mathrm{O}$ signatures observed among different parts of the island; thus suggesting that the oxygen data reflect climatic variation and probably represent more than one site.

Two additional points that will be worthwhile to look into are the potential chronological and/or spatial patterning of human isotopic data. Because studies on the chronology of the bioachaeological data of the site are in progress we are not yet able to conclusively discuss these, once these studies are completed and the relevant data are finalized we will examine 
503

504

505

506

507

508

509

510

511

512

513

514

515

516

517

518

519

520

521

522

523

524

525

526

527

528

529

530

531

532

533

them against the isotopic data from the site with a view to furthering our understanding of the observed data variation.

\section{Conclusions}

The human strontium and oxygen isotope signatures are in line with a local origin within the broader region of Sissi. The strontium isotope values, in particular, point to a diverse substrate geology in agreement with that reported for Sissi and its immediate surroundings within a $5 \mathrm{~km}$ radius (Creutzburg, 1977), while the oxygen data match the variation of modern precipitation $\delta^{18} \mathrm{O}$ values from different parts of the island and point to variability in climate linked to distance to the sea and/or altitude. The human strontium and oxygen results thus point to the use of different feeding territories in proximity to the site and possibly also variation in childhood diet. It seems therefore plausible that at Pre- and Protopalatial Sissi short-range mobility that needed not exceed a radius of $5 \mathrm{~km}$ was part of people's lives. Either they were moving as part of their daily routine to cultivate the land, herd their flocks and/or hunt or fish, or some of them had relocated from sites nearby, or even both.

Maximization of the exploitation of arable land to extend the agricultural resource base largely coincides with settlement nucleation and population growth towards the late Prepalatial period, while use of multiple production zones by the people at Sissi may also be seen as a buffer against climate instability and vulnerability of coastal sites.

Due to overlapping strontium and oxygen isotope signatures it is impossible to choose between potential sites of origin within the island of Crete or the central Cyclades. Even if nonlocals are indeed present amongst the Sissi individuals tested, based on information of the substrate geology of the island and modern precipitation $\delta^{18} \mathrm{O}$ data, they did not need to have originated from outside Crete or sites on the island at a great distance from Sissi. They could have moved in from nearby villages across the Malia bay, such as the roughly contemporary site of Malia to the west, or the Neapolis area to the south-east of Sissi, respectively. Although we cannot discard this scenario, based on the bioavailable strontium and modern precipitation oxygen data from the broader Sissi region we favor the theory for a local origin within this region and mobile lifeways at least for the majority of the people studied. 
535 We are grateful to the Ephorate of Antiquities of Lasithi for facilitating our research at Sissi

536 in general and on diet and mobility in particular and also for their permission to sample the

537 archaeological skeletal collection from the site for the purposes of this work. Research at Sissi

538 is funded by the UCLouvain, INSTAP, the Belgian School at Athens, the Loeb Classical

539 Library, the Rust Family Foundation, the FNRS, the CNRS and private sponsors. Travel

540 expenses and the analytical costs for the oxygen isotope ratio analysis were covered through

541 research funding from a Marie Skłodowska-Curie Individual Fellowship and a grant from the

542 D.M. McDonald Grants and Awards Fund that were both awarded to A. Nafplioti for her

543 project entitled EPOCH GeoChem (project number 654736), while the Katholieke

544 Universiteit Leuven via I. Schoep sponsored the strontium analyses. Without the above

545 financial support this research would not have been possible.

\section{References}

549 Bentley, R.A. 2006. Strontium isotopes from the earth to the archaeological skeleton: A 550 review. Journal of Archaeological Method and Theory 13, 135-187.

551 Bentley, R.A., Knipper, C. 2005. Geographic patterns in biologically available strontium, 552 carbon and oxygen isotopes signatures in prehistoric SW Germany. Archaeometry 47, 62955344.

554 Bentley, R.A., Pietrusewsky, M., Douglas, M.T., Atkinson, T.C. 2005. Matrilocality during 555 the prehistoric transition to agriculture in Thailand? Antiquity 79(306), 865-881.

556 Bentley, R.A., Price, T.D., Stephan, E., 2004. Determining the 'local' ${ }^{87} \mathrm{Sr} /{ }^{86} \mathrm{Sr}$ range for 557 archaeological skeletons: a case study from Neolithic Europe. Journal of Archaeological 558 Science 31, 365-375.

559 Betancourt, P.P. 2012. The frying pans from Hagia Photia. In Mantzourani, E., Betancourt, 560 P.P. (Eds.), PHILISTOR. Studies in Honor of Costis Davaras, Philadelphia, pp. 1-6.

561 Blum, J.D., Taliaferro, E.H., Weisse, M.T., Holmes, R.T., 2000. Changes in $\mathrm{Sr} / \mathrm{Ca}, \mathrm{Ba} / \mathrm{Ca}$, 562 and ${ }^{87} \mathrm{Sr} /{ }^{86} \mathrm{Sr}$ ratios between trophic levels in two forest ecosystems in the Northeastern USA. 563 Biogeochemistry 49, 87-101. 
564

565

566

567

568

569

570

571

572

573

574

575

576

577

578

579

580

581

582

583

584

585

586

587

588

589

590

591

592

Bowen GJ, Revenaugh J. 2003. Interpolating the isotopic composition of modern meteoric precipitation. Water Resources Research 39:1-13.

Branigan, K. 1971. Cycladic figurines and their derivatives, Annual of the British School at Athens 66, 57-78.

Branigan, K. 1974. Aegean Metalwork of the Early and Middle Bronze Age. Oxford Monographs on Classical Archaeology, Oxford.

Branigan, K. 1984. Minoan Community Colonies in the Aegean? In R. Hagg, N. Marinatos (Eds.), The Minoan Thalassocracy: Myth and Reality. Acts of the Swedish Institute at Athens. Swedish Institute at Athens, Stockholm, pp. 49-53.

Broodbank, C. 2000. An Island Archaeology of the Early Cyclades. Cambridge University Press, Cambridge.

Bryant, J. D., Koch, P., Froelich, P. N., Showers, W. J., and Genna, B. J., 1996. Oxygen isotope partitioning between phosphate and carbonate in mammalian apatite. Geochimica et Cosmochimica Acta 60, 5145-8.

Carter, T. 1998. Reverberations of the International Spirit: Thoughts upon 'Cycladica' in the Mesara. In K. Branigan, K. (Ed.), Cemetery and Society in the Bronze Age. Sheffield Studies in Aegean Archaeology 1. Sheffield Academic Press, Sheffield, pp. 59-77.

Caskey, J.L. 1960. The Early Helladic Period in the Argolid. Hesperia 29, 285-303.

Chenery, C.A., Muldner, G., Evans, J.A., Eckardt, H., Lewis, M. 2010. Strontium and stable isotope evidence for diet and mobility in Roman Gloucester, UK. Journal of Archaeological Science 37, 150-63.

Chenery, C.A., Pashley, V., Lamb, A.L., Sloane H.J., Evans J.A. 2012. The oxygen isotope relationship between the phosphate and structural carbonate fractions of human bioapatite. Rapid Communications in Mass Spectrometry 26(3), 309-19.

Childe, G.V. 1957. The Dawn of European Civilization. Routledge and Kegan Paul, London.

Coleman, J. 1988. Greece and the Aegean.

Coplen, T., 1995. New IUPAC Guidelines for the Reporting of Stable Hydrogen, Carbon and Oxygen Isotope Ratio Data. Journal of Research of the National Institute of Standards and Technology 100, 285. 
593 Creutzburg, N. 1977. General geological map of Greece, Crete Island (1:200.000). Institute of

594 Geological and Mining Research, Athens.

595 Crevecoeur, I., Schmitt, A. 2009. Etude archéo-anthropologique de la nécropole (Zone 1). In 596 J. Driessen, I. Schoep, F. Carpentier, I. Crevecoeur, M. Devolder, F. Gaignerot-Driessen, P. 597 Hacigüzeller, S. Jusseret, C. Langohr, Q. Letesson \& A. Schmitt (Eds.) Excavations at Sissi. 598 Preliminary Report on the 2007-2008 Campaigns (Aegis 1). Presses Universitaires de 599 Louvain, pp. 57-94.

600 Crevecoeur, I., Schmitt, A., Scheop, I. 2015. An archaeothanatological approach to the study 601 of Minoan funerary practices. Case-studies from the Early and Middle Minoan cemetery at 602 Sissi, Crete. Journal of Field Archaeology 40, 283-299.

603 D'Angela, D., Longinelli, A. 1990. Oxygen isotopes in living mammal's bone phosphate: 604 Further results. Chemical Geology (Isotope Geoscience Section) 86, 75-82.

605 Daux, V., Lécuyer, C., Héran, M-A., Amiot, R., Simon, L., Fourel, F., Martineau, F., 606 Lynnerup, N., Reychler, H., Escarguel, G. 2008. Oxygen isotope fractionation between 607 human phosphate and water revisited. Journal of Human Evolution 55, 1138-47.

608 Day, P., Hein, A., Joyner, L., Kilikoglou,V., Kiriatzi, E., Tsolakidou, A., Wilson, D.E. 2012. 609 Appendix A. Petrographic and chemical analysis of the pottery. In C. Davaras, P. Betancourt 610 (Eds.), The Hagia Photia Cemetery II. The Pottery. Prehistory monographs, 34. INSTAP 611 Academic Press, Philadelphia, pp. 115-38.

612 Day, P.M, Wilson, D.E., Kiriatzi, E. 1998. Pots, Labels, and People: Burying Ethnicity in the 613 Cemetery at Aghia Photia, Siteias. In K. Branigan (Ed.), Cemetery and Society in the Aegean 614 Bronze Age. Sheffield Studies in Aegean Archaeology 1. Sheffield Academic Press, 615 Sheffield, pp. 133-49.

616 DeNiro, M.J. Epstein, S. 1981. Influence of diet on the distribution of nitrogen isotopes in 617 animals. Geochimica et Cosmochimica Acta 45, 341-351.

618 Doonan, R., Day, P. 2007. Mixed origins and the origins of mixing: Alloys and provenance in 619 the Early Bronze Age Aegean. In P. Day, R. Doonan (Eds.), Metallurgy in the Early Bronze 620 Age Aegean. Oxbow books, Oxford, pp.1-19.

621 Doumas, C. 1976. Prehistoric Cycladers on Crete (in Greek). Archaeologika Analekta 622 Athinon 9, 69-79.

623 Doumas, C. 1977. Early Bronze Age Burial Habits in the Cyclades. Studies in Mediterranean 624 Archaeology, 48. Paul Åströms Förlag, Göteborg. 
625 Driessen, J., Anastasiadou, M., Caloi, I., Claeys, T., Déderix, S., Devolder, M., Jusseret, S., 626 Langohr, C., Letesson, Q., Mathioudaki, I., Mouthuy, O., Schmitt, A. 2018. Excavations at 627 Sissi IV. Preliminary Report on the 2015-2016 Campaign (Aegis 13). Presses Universitaires 628 de Louvain.

629 Driessen, J., Schoep, I., Anastasiadou, M., Carpentier, F., Crevecoeur, I., Déderix, S., 630 Devolder, M., Gaignerot-Driessen, F., Jusseret, S., Langohr, C., Letesson, Q., Liard, F., 631 Schmitt, A., Tsoraki C, Veropoulidou, R. 2012. Excavations at Sissi III. Preliminary Report 632 on the 2011 Campaign (Aegis 6). Presses Universitaires de Louvain.

633 Driessen, J., Schoep, I., Carpentier, F., Crevecoeur, I., Devolder, M., Gaignerot-Driessen, F., 634 Hacigüzeller, P., Jusseret, S., Langohr, C., Letesson, Q., Schmitt, A. 2009. Excavations at 635 Sissi. Preliminary Report on the 2007-2008 Campaigns (Aegis 1). Presses Universitaires de 636 Louvain.

637 Driessen, J., Schoep, I., Carpentier, F., Crevecoeur, I., Devolder, M., Gaignerot-Driessen, F., 638 Hacigüzeller, P., Isaakidou, V., Jusseret, S., Langohr, C., Letesson, Q., Schmitt, A. 2011. 639 Excavations at Sissi II. Preliminary Report on the 2009-2010 Campaigns (Aegis 4). Presses 640 Universitaires de Louvain.

641 Eckardt, H., Chenery, C., Booth, P., Evans, J.A., Lamb, A., Muldner, G. 2009. Oxygen and 642 strontium isotope evidence for mobility in Roman Winchester. Journal of Archaeological 643 Science $36,2816-25$.

644 Elderfield, H. 1986. Strontium isotope stratigraphy. Palaeogeography, Palaeoclimatoly, 645 Palaeoecology 57, 71-90.

646 Ericson, J.E. 1985. Strontium isotope characterization in the study of prehistoric human 647 ecology. Journal of Human Evolution 14, 503-14.

648 Evans, J.A., Montgomery, J., Wildman, G. 2009. Isotope domain mapping of ${ }^{87} \mathrm{Sr} /{ }^{86} \mathrm{Sr}$ 649 biosphere variation on the Isle of Skye Scotland. Journal of Geological Society 166, 617-31.

650 Ezzo, J.A., Johnson, C.M., Price, T.D., 1997. Analytical perspectives on prehistoric 651 migration: a case study from east-central Arizona. Journal of Archaeological Science 24, 44765266.

653 Ezzo, J., Price, T.D. 2002. Migration, regional reorganization, and spatial group composition 654 at Grasshopper Pueblo, Arizona. Journal of Archaeological Science 29, 499-520.

655 Faure, G. 1986. Principles of Isotope Geology. John Wile and Sons, New York. 
656 Gat, J.R. 1980. The isotopes of hydrogen and oxygen in precipitation. In P. Fritz, J.C. Fontes

657 (Eds.), Handbook of Environmental Isotope Geochemistry. Elsevier Press, Amsterdam, 658 pp.21-47.

659 Gkalanaki, K.(Ed.), 2020. Gournes, Pediada: A Minoan Cemetery in Crete. INSTAP 660 Academic Press.

661 Graustein, W.C. $1989 .{ }^{87} \mathrm{Sr} /{ }^{86} \mathrm{Sr}$ ratios measure the sources and flow of strontium in terrestrial 662 ecosystems. In P.W. Rundel, J.R. Ehleringer, K.A. Nagy (Eds.), Stable isotopes in ecological 663 research. Springer-Verlag, New York, pp. 491-512.

664 Grupe, G., Price, T.D, Schorter, P., Sollner, F., Johnson, C., Beard, B., 1997. Mobility of Bell 665 Beaker people revealed by stable strontium isotope ratios of teeth and bones. A study of 666 southern Bavarian skeletal remains. Applied Geochemistry 12, 517-25.

667 Haggis, D. 1999. Staple Finance, Peak Sanctuaries, and Economic Complexity in Late 668 Prepalatial Crete. In A. Chaniotis (Ed.), From Minoan Farmers to Roman Traders: Sidelights 669 on the Economy of Ancient Crete (HABES, 29). Stuttgart, pp. 53-85.

670 Higgins, M.D., Higgins, R., 1996. A Geological Companion to Greece and the Aegean. 671 Duckworth, London.

672 Hillson, S. 2002. Dental Anthropology, third edition. Cambridge University Press, 673 Cambridge

674 Hoefs, J. 1997. Stable Isotope Geochemistry. Springer, Berlin.

675 Hoppe, K.A., Koch, P.L., Furutani, T.T. 2003. Assessing the preservation of biogenic 676 strontium in fossil bones and tooth enamel. International Journal of Osteoarchaeology 13(1), $677 \quad 20-8$.

678 Hughes, S.S., Millard, A.R., Lucy, S.J., Chenery, C., Evans, J.A., Nowell, G., Pearson, D.G. 679 2014. Anglo-Saxon origins investigated by isotopic analysis of burials from Berinsfield, 680 Oxfordshire, UK. Journal of Archaeological Science 42, 81-92.

681 Iacumin, P., Bocherens, H., Mariotti, A. Longinelli, A. 1996. Oxygen isotope analyses of co682 existing carbonate and phosphate in biogenic apatite: a way to monitor diagenetic alteration of 683 bone phosphate? , 142: 1-6. 
684

685

686

687

688

689

690

691

692

693

694

695

696

697

698

699

700

701

702

703

704

705

706

707

708

709

710

711

712

713

714

Jay, M., Fuller, B.T., Richards, M.P., Knusel, C.J., King, S.S. 2008. Iron Age breastfeeding practices in Britain: isotopic evidence from Wetwang Slack, East Yorkshire. American Journal of Physical Anthropology 136, 327-37.

Knudson, K.J., Price, T.D. 2007. Utility of multiple chemical techniques in archaeological residential mobility studies: Case studies from Tiwanaku- and Chiribaya- affiliated sites in the Andes. American Journal of Physical Anthropology 132(1), 25-39.

Kohn, M.J., Schoeninger, M.J., Valley J.W. 1996. Herbivore tooth oxygen isotope compositions: Effects of diet and physiology. Geochimica et Cosmochimica Acta 60, 388996.

Legarra Herrero, B. 2009. The Minoan fallacy: Cultural diversity and mortuary behaviour on Crete at the beginning of the Bronze Age. Oxford Journal of Archaeology 28, 28-57.

Legarra Herrero, B. 2014. Mortuary behaviour and social trajectories in Pre- and Protopalatial Crete. INSTAP Academic Press, Philadelphia:

Levinson, A.A., Luz, B., Kolodny, Y. 1987. Variations in oxygen isotope compositions of human teeth and urinary stones. Applied Geochemistry 2, 367-371.

Lightfoot, E., O'Connell, T.C. 2016. On the Use of Biomineral Oxygen Isotope Data to Identify Human Migrants in the Archaeological Record: IntraSample Variation, Statistical Methods and Geographical Considerations. PLoS ONE 11(4): e0153850.

Longinelli, A. 1984. Oxygen isotopes in mammal bone phosphate: a new tool for paleohydrological and paleoclimatological research? Geochimica et Cosmochimica Acta 48, 385-90.

Luz, B, Kolodny, Y.1985. Oxygen isotope variations in phosphate of biogenic apatites, IV. Mammal teeth and bones. Earth and Planetary Science Letters 75(1), 29-36.

Lykoudis, S.P., Argiriou, A.A. 2007. Gridded data set of the stable isotopic composition of precipitation over the eastern and central Mediterranean. Journal of Geophysical Research, 112.

Manning, S.W. 1994. The emergence of the divergence: development and Decline on the Bronze Age Crete and the Cyclades. In C. Mathers, S. Stoddart (Eds.), Development and Decline in the Mediterranean Bronze Age. Sheffield Archaeological Monographs 8, University of Sheffield, J.R. Collis, pp. 221-270.

Mee, C. 1982. Rhodes in the Bronze Age. Warminster Wits. 
Mellaart, J. 1975. The Neolithic of the Near EastThames \& Hudson, London:

Miller, E.K., Blum, J.A., Friedland, A.J., 1993. Determination of soil exchangeable-cation loss and weathering rates using Sr isotopes. Nature 362, 438-441.

Mitchell, P.D., Millard, A.R. 2009. Migration to the Medieval Middle East with the Crusades. American Journal of Physical Anthropology 140(3), 518-25

Montgomery, J. 2002. Lead and strontium isotope compositions of human dental tissues as an indicator of ancient exposure and population dynamics. Bradford university, Bradford.

Montgomery, J., Evans, J.A., Neighbour, T., 2003. Sr isotope evidence for population movement within the Hebridean Norse community of NW Scotland. Journal of Geological Research 160, 649-53.

Montgomery, J. Evans, J.A., Cooper, R.E. 2007. Resolving archaeological populations with Sr-isotope mixing models. Applied Geochemistry 22, 1502-14.

Montgomery, J., Evans, J.A. 2009. Immigrants on the Isle of Lewis - combining traditional funerary and modern isotope evidence to investigate social differentiation, migration and dietary change in the Outer Hebrides of Scotland. In R. Gowland, C. Knusel (Eds.), The social Archaeology of Funerary Remains, Oxbow books, Oxford, pp. 122-42.

Moody, J. 2012. Hinterlands and hinterseas: resources and production zones in Bronze Age and Iron Age Crete. BSA Studies Vol. 20, Parallel lives: island societies in Crete and Cyprus, pp. 233-71.

Muldner, G., Chenery, C., Eckardt, H. 2011. The 'headless Romans': multi-isotope investigations of an unusual burial ground from Roman Britain. Journal of Archaeological Science 38, 280-90.

Mylonas, G.E. 1959. Aghios Kosmas. An Early Bronze Age Settlement and Cemetery in Attica. Princeton University Press, Princeton.

Nafplioti, A. 2007. Population bio-cultural history in the South Aegean during the Bronze Age. Unpublished $\mathrm{PhD}$ thesis, University of Southampton, Southampton.

Nafplioti, A. 2008. Mycenaean political domination of Knossos following the LMIB destructions on Crete: negative evidence from strontium isotope ratio analysis $\left({ }^{87} \mathrm{Sr} /{ }^{86} \mathrm{Sr}\right)$. Journal of Archaeological Science 35, 2307-17. 
Nafplioti, A. 2009a. Mycenae Revisited part 2. Exploring the local vs. non-local origin of the individuals from Grave Circle A at Mycenae: evidence from strontium isotope ratio $\left({ }^{87} \mathrm{Sr} /{ }^{86} \mathrm{Sr}\right)$ analysis. Annual of the British School at Athens 104, 279-291.

Nafplioti, A. 2009b. Early Bronze Age Manika on Euboea (Greece): A 'colony' or Not? Evidence from strontium isotope ratio $\left({ }^{87} \mathrm{Sr} /{ }^{86} \mathrm{Sr}\right)$ analysis. Geochimica et Cosmochimica Acta 73(13), Suppl. 1, A925.

Nafplioti, A. 2011. Tracing population mobility in the Aegean using isotope geochemistry: a first map of biologically available ${ }^{87} \mathrm{Sr} /{ }^{86} \mathrm{Sr}$ signatures. Journal of Archaeological Science 38, 1560-70.

Nafplioti, A. 2012a. Strontium isotope ratio $\left({ }^{87} \mathrm{Sr} /{ }^{86} \mathrm{Sr}\right)$ analysis in past population mobility studies: Snails as local bioavailable ${ }^{87} \mathrm{Sr} /{ }^{86} \mathrm{Sr}$ tracers. In Miahua Wai, Xu Guan Gong (Eds.) Strontium: Chemical Properties, Applications and Health Effects. Nova Publishers, New York.

Nafplioti, A. 2012b. Late Minoan IB destructions and cultural upheaval on Crete: A bioarchaeological perspective. In E. Kaizer, J. Burger, Schier, W. (Eds), Population Dynamics in Prehistory and Early History: New Approaches using Stable Isotopes and Genetics, De Gruyter, Berlin, pp.241-64.

Nafplioti, A. 2015. Residential mobility at Myrtos Pyrgos? In C.F. Macdonald, E. Hatzaki, S. Andreou (eds), Studies of Crete and Cyprus presented to Gerald Gadogan, pp. 90-93. Athens: KAPON Editions.

Nafplioti, A. 2020. The Human Skeletal Remains: The question of the missing bones. In K. Gkalanaki (Ed.), Gournes, Pediada: A Minoan Cemetery in Crete, Vol. I. INSTAP Academic Press, Philadelphia.

Palmer, M.R., Elderfield, H. 1985. Sr isotope composition of sea water over the past 75 Myr. Nature 314, 526-28.

Papadatos, Y. 1999. Mortuary practices and their importance for the reconstruction of society and life in Prepalatial Crete: The evidence from Tholos Tomb $\Gamma$, in Archanes-Phourni'. Unpublished PhD thesis, University of Sheffield, Sheffield.

Papadatos, Y. 2007. Beyond cultures and ethnicity: A new look at material culture distribution and inter-regional interaction in the Early Bronze Age southern Aegean. In S. Antoniadou, A. Pace (Eds.), Mediterranean Crossroads, Pierides Foundation, Athens, pp. 41951. 
Papavasileiou, G. 1910. The ancient graves on Euboea (in Greek). Athena: Vivliothiki tis en Athinais Archaeologikis Etairias 15.

Pollard, A.M., Pellegrini, M., Lee-Thorp, J.A. 2011. Technical Note: Some observations on the conversion of dental enamel $\delta^{18} \mathrm{Op}$ values to $\delta^{18} \mathrm{Ow}$ to determine human mobility. American Journal of Physical Anthropology145(3), 499-504.

Price, T.D., Johnson, C.M., Ezzo, J.A., Burton, J.H., Ericson, J.A. 1994. Residential mobility in the late prehistoric Southwest: A preliminary study using strontium isotope ratios. Journal of Archaeological Science 24, 315-30.

Price, T.D., Manzanilla, L., Middleton, W.H. 2000. Residential mobility at Teotihuacan: a preliminary study using strontium isotopes. Journal of Archaeological Science 27, 903-13.

Price, T.D., Burton, J.H., Bentley, R.A. 2002. The characterization of biologically available strontium isotope ratios for the study of prehistoric migration. Archaeometry 44, 117-35.

Pryor, A.J.E, Stevens, R.E., O'Connell, T.C., Lister, J.R. 2014. Quantification and propagation of errors when converting vertebrate biomineral oxygen isotope data to temperature for palaeoclimate reconstruction. Palaeogeography Palaeoclimatology Palaeoecology 412, 99-107.

Redfern, R.C., Grocke, D.R., Millard, A.R., Ridgeway, V., Johnson, L., Hefner, J.T. 2016. Going south of the river: A multidisciplinary analysis of ancestry, mobility and diet in a population from Roman Southwark, London. Journal of archeological Science 74, 11-22.

Rogers, G., Hawkesworth, C.J., 1989. A geochemical traverse across the North Chilean Andes: evidence for crust generation from the mantle wedge. Earth and Planetary Science letters 91, 271-85.

Sampson, A. 1988. Manika II: The Early Helladic settlement and cemetery (in Greek). Municipality of Chalkis, Athens.

Sampson, A., Hadji, A. 2019. Manika Revisited: A recontextualisation of Euboean Cycladica in the light of new research. In M. Marthari, C. Renfrew, M.J. Boyd (Eds.), Beyond the Cyclades: Early Cycladic Sculpture in Context from Mainland Greece, the North and East Aegean. Oxbow books, Oxford, pp. 163-7.

Sapouna-Sakellarakis, E. 1987. New evidence from the Early Bronze Age Cemetery of Manika, Chalkis. Annual of the British School at Athens 82, 233-64.

Scheuer, L., Black, S. 2000. Developmental Juvenile Osteology. London. 
807

808

809

810

811

812

813

814

815

816

817

818

819

820

821

822

823

824

825

826

827

828

829

830

831

832

833

834

835

836

837

Schmitt A., Sperandio E. 2018. The Cemetery (Zone 9). Report on the 2016 Campaign. In J. Driessen, M. Anastasiadou, I. Caloi, T. Claeys, S. Déderix, M. Devolder, S. Jusseret, C. Langohr, Q. Letesson, I. Mathioudaki, O. Mouthuy, A. Schmitt (Eds.) Excavations at Sissi IV. Preliminary Report on the 2015-2016 Campaigns, pp. 59-76. Presses Universitaires de Louvain, Louvain.

Schoep I., Schmitt A., Crèvecoeur I. 2011. The Cemetery at Sissi (Zone 1 \& 9). In J. Driessen, I. Schoep, F. Carpentier, I. Crevecoeur, M. Devolder, F. Gaignerot-Driessen, P. Hacigüzeller, V. Isaakidou, S. Jusseret, C. Langohr, Q. Letesson, A. Schmitt, (Eds.), Excavations at Sissi. Report on the 2009-2010 campains. Presses Universitaires de Louvain, Louvain, pp. 39-64.

Schoep I., Schmitt A., Crèvecoeur I., Déderix S., 2012. The Cemetery at Sissi, report of the 2011 Campaing. In Driessen, J., Schoep, I., Anastasiadou, M., Carpentier, F., Crevecoeur, I., Déderix, S., Devolder, M., Gaignerot-Driessen, F., Jusseret, S., Langohr, C., Letesson, Q., Liard, F., Schmitt, A., Tsoraki C, Veropoulidou, R. (Eds.), Excavations at Sissi. Preliminary Report on the 2011 campains. Presses Universitaires de Louvain, Louvain, pp. 27-50.

Scull, C. 1995. Approaches to material culture and social dynamics of the Migration Period in eastern England. In J. Bintliffe, H. Hamerow (Eds.), Europe between Late Antiquity and the Middle Ages: recent archaeological and historical research in western and southern Europe. BAR S617, Oxford, 71-83.

Tafuri, M., Bentley, R.A., Manzi, G., di Lernia, S., 2006. Mobility and kinship in the prehistoric Sahara: Strontium isotope analysis of Holocene human skeletons from the Acacus Mts. (southwestern Libya). Journal of Anthropological Archaeology 25, 390-402.

Theocharis, D. 1959. Prehistoric Euboea and Skyros (in Greek). Archeion Euvoikon Meleton 6, 279-325.

Tringham, R. 1971. Hunters, fishers and farmers of Eastern Europe 6000-3000 BC. Hutchinson University Library, London.

Ubelaker, D.H. 1989. Human Skeletal Remains. Taraxacum Press, Washington.

van der Merwe, N. J. 1982. Carbon isotopes, photosynthesis and archaeology. Scientific American 70, 546-606.

Vavouranakis, G. 2007. Funerary Landscapes East of Lasithi, Crete, in the Bronze Age. British Archaeological Reports 1606, Oxford. 
838

839

840

841

842

843

844

845

846

847

848

849

850

851

852

853

854

855

856

857

858

859 Wright, L.E., Schwarcz, H.P., 1998. Stable carbon and oxygen isotopes in human tooth

860 enamel: identifying breastfeeding and weaning in prehistory. American Journal of Physical

861 Anthropology 106, 1-18.

862 Yurtsever, Y., Gat, J. R. 1981. Atmospheric waters. In J. R. Gat, R. Gonflantini (Eds.), Stable

863 Isotope Hydrology: Deuterium and Oxygen-18 in the Water Cycle. Technical Report Series 864

Veizer, J., 1989. Strontium isotopes in seawater through time. Annual Review of Earth and Planetary Sciences 1, 141-67.

Warren, P.M. 1973. Crete, 3000-1400BC: Immigration and the archaeological evidence. In R.A Crossland, A. Birchall (Eds.), Bronze Age Migrations in the Aegean: Archaeological and Linguistic Problems in Greek Prehistory. Gerald Duckworth \& Ltd, London, pp. 41-7.

White, C.D., Longstaffe, F.J., Spence, M.W., Law, K.R. 2000. Teotihuacan state representation at Kaminaljuyu: evidence from oxygen isotopes. Journal of Anthropological Research 56, 535-58.

White, C.D., Spence, M.W., Longstaffe, F.J., Law, K.R. 2004. Demography and ethnic continuity in the Tlailotlacan enclave of Teotihuacan: the evidence from stable oxygen isotopes. Journal of Anthropological Archaeology 23, 385-403.

White, C.D., Spence, M.W., Stuart-Williams, H.L.Q., Schwarcz, H.P. 1998. Oxygen isotopes and the identification of geographical origins: the Valley of Oaxaca versus the Valley of Teotihuacan. Journal of Archaeological Science 25, 643-55.

Wilson, D.E., Day, P.M. Dimopoulou, N. 2004. The pottery from Early Minoan IIIB Knossos and its relations with the harbour site of Poros Katsambas. In G. Cadogan, E. Hatzaki, A. Vasilakis (Eds.), Knossos: Palace, City, State. British School at Athens Studies Series 12, London, pp. 67-74.

Wright, L.E. 2005. Identifying immigrants to Tikal, Guatemala: Defining local variability in strontium isotope ratios of human tooth enamel. Journal of Archaeological Science 32, 55566.

no. 210, International Atomic Energy Agency, Vienna, pp. 103-142. 


\section{List of tables}

Table $1 .{ }^{87} \mathrm{Sr} /{ }^{86} \mathrm{Sr}$ and $\delta^{18} \mathrm{O}$ ratios from and basic archaeological and anthropological information on the individuals sampled from Sissi.

Table 2. Descriptive statistics for ${ }^{87} \mathrm{Sr} /{ }^{86} \mathrm{Sr}$ values from Sissi human enamel, for the complete and trimmed data sets. 


\section{List of Figures}

Figure 1. Map of the Aegean; marked on it is the site of Sissi.

Figure 2. Site plan of Bronze Age Sissi on Crete showing all zones excavated.

Figure 3. Plan of the Pre- and Protopalatial cemetery at Sissi showing the locations where the samples analysed were recovered from (edited by J. Driessen).

Figure 4. Strontium and oxygen (phosphate and calculated drinking water values) isotope ratios for individuals from Sissi.

The circle denotes samples from M1s which are probably affected by the breastfeeding effect. The star and triangle mark M2s and M3s, respectively, which form after individuals were weaned. Shown on the graph are the estimated range of bioavailable ${ }^{87} \mathrm{Sr} /{ }^{86} \mathrm{Sr}$ signatures measured from snails found within a $6 \mathrm{~km}$ radius around Sissi, and the range for the oxygen isotope composition of modern precipitation on Crete (after Lykoudis and Argyriou 2007) .

Figure 5. Histogram of the complete Sissi human enamel ${ }^{87} \mathrm{Sr} /{ }^{86} \mathrm{Sr}$ data set, with normal distribution curve for comparison.

Figure 6. Histogram of the trimmed Sissi human enamel ${ }^{87} \mathrm{Sr} /{ }^{86} \mathrm{Sr}$ data set, with normal distribution curve for comparison.

Figure 7. Strontium isotope ratio $\left({ }^{87} \mathrm{Sr} /{ }^{86} \mathrm{Sr}\right)$ values from human enamel samples from Sissi and snail shell values from the broader region.

Key: BARS: black=human dental enamel, white=human bone, grey= snail shell.

Figure 8. Strontium and corrected oxygen (phosphate and calculated drinking water values) isotope ratios for individuals from Sissi.

The circle denotes oxygen values from M1s corrected for a potential breastfeeding effect, while the star and triangle mark M2s and M3s, respectively, which form after individuals were weaned. 


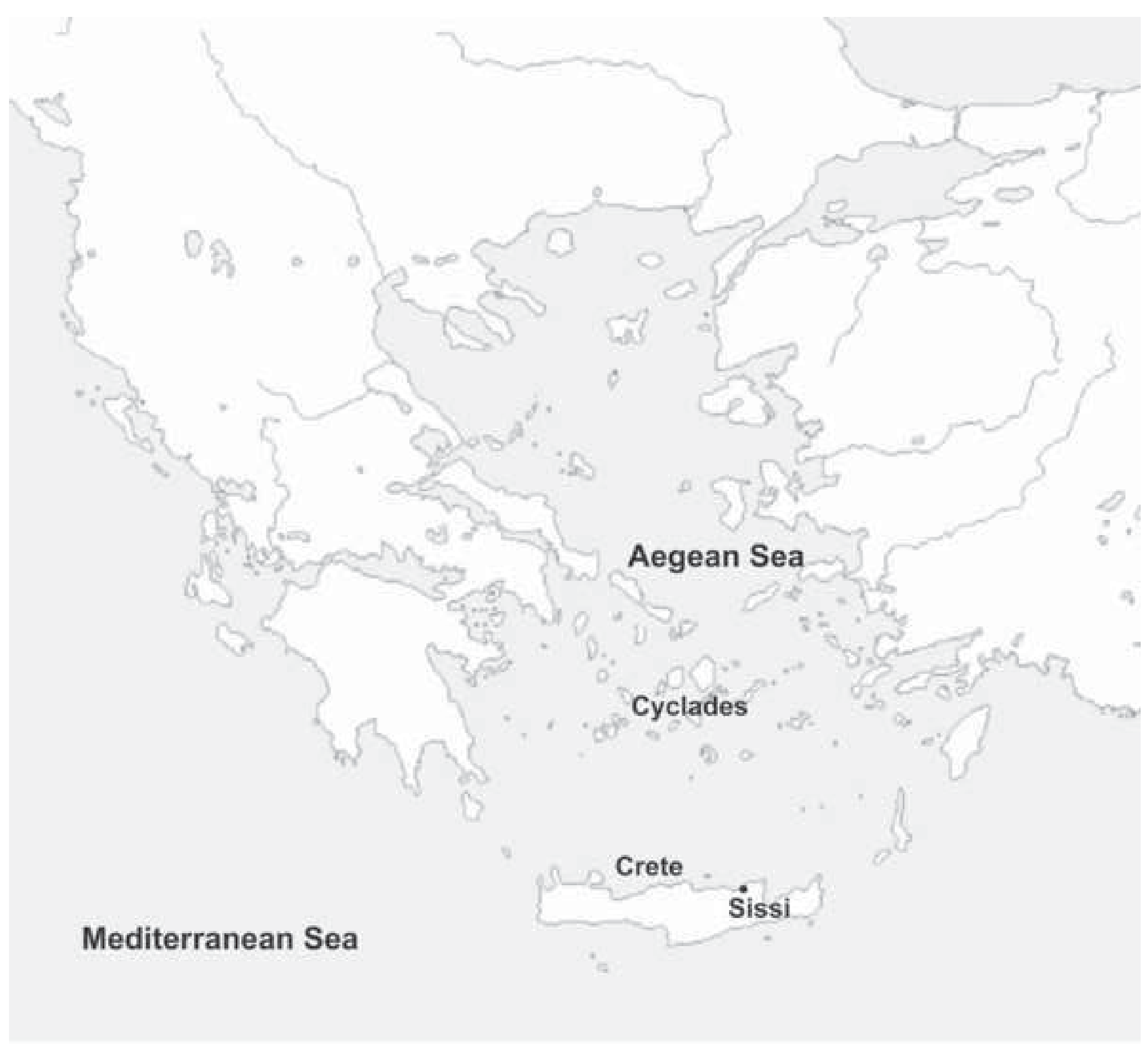



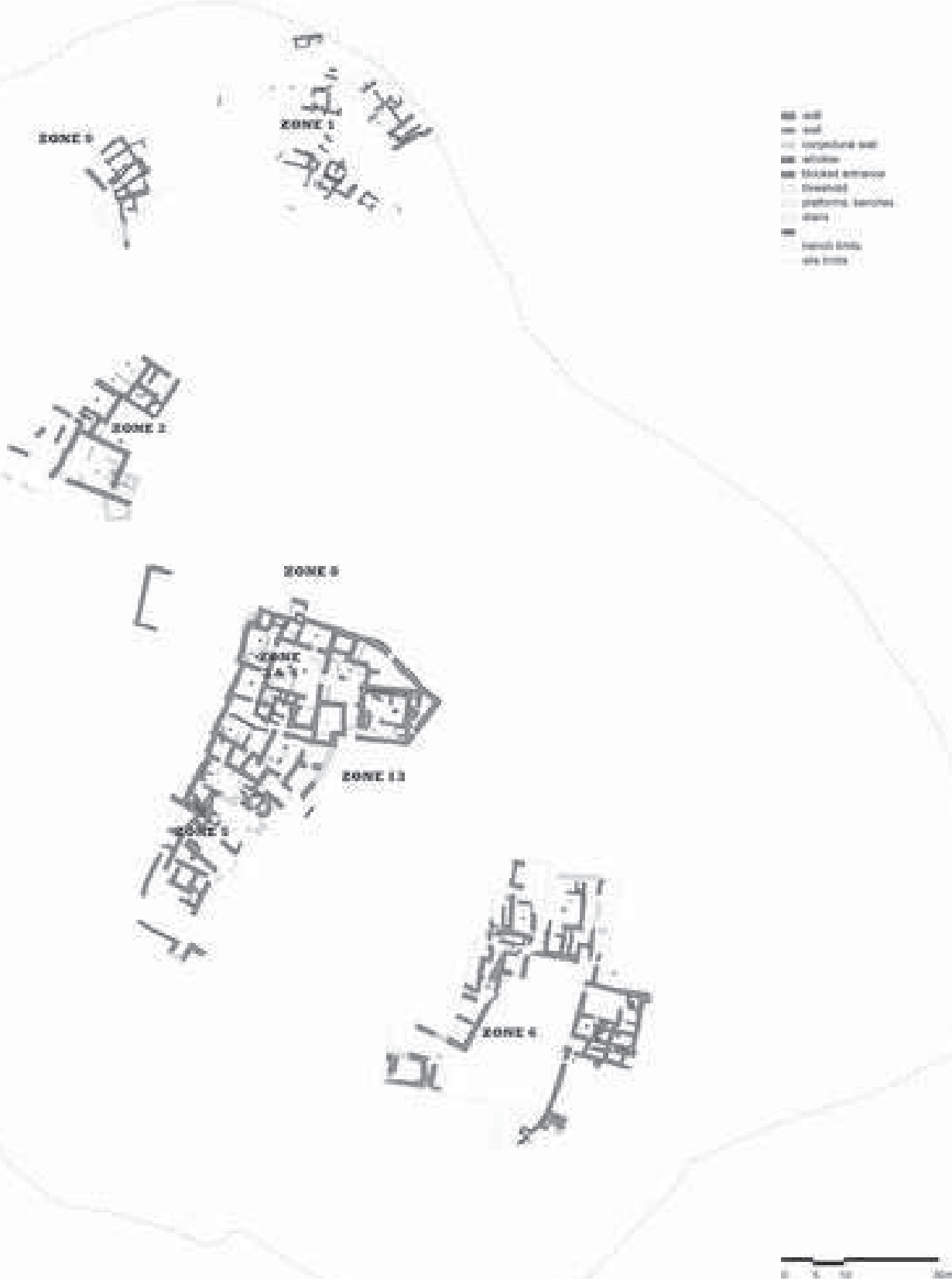


\begin{tabular}{|c|c|c|}
\hline \multicolumn{3}{|c|}{ 'SISSI ARCHAEOLOGICAL PROJECT', CRETE } \\
\hline \multicolumn{2}{|c|}{ BELGIAN SCHOOL AT ATHENS } & \multirow{9}{*}{ 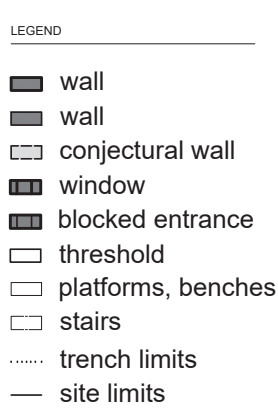 } \\
\hline DOCUMENTATION DATE: 2016-18 & DOCUMENTATION DATE: 2011-13 & \\
\hline SuRver: & SURVEY: & \\
\hline $\begin{array}{l}\text { ZOGRAFOU ELEFFHERIA } \\
\text { ARCHITECT ENGINEER }\end{array}$ & $\begin{array}{l}\text { GOUULOPOULOUU VASSLLIIII } \\
\text { RURAL \& SURVEYING ENGIIEER }\end{array}$ & \\
\hline $\begin{array}{l}\text { PATERAKI MARLLENA } \\
\text { ARCHITECT ENGINEER }\end{array}$ & $\begin{array}{l}\text { CHALKIDI AFRODITI } \\
\text { ARCHTCCT NGINER }\end{array}$ & \\
\hline $\begin{array}{l}\text { ARCUTLCAFTIS CHRRISTOS } \\
\text { ARCHITECT ENGINERR }\end{array}$ & $\begin{array}{l}\text { ARSI MARIANA } \\
\text { ARCHITECT ENGINEER }\end{array}$ & \\
\hline \multirow{2}{*}{\multicolumn{2}{|c|}{$\begin{array}{l}\text { DRAWMGG } \\
\text { ZOGRAFOU ELEFTHERIA } \\
\text { ARCHITECT ENGINEER }\end{array}$}} & \\
\hline & & \\
\hline \multicolumn{2}{|c|}{$\begin{array}{l}\text { DRAWING: } \\
\text { ZONES 1.9 PRELIMINARY OUTLINE PLAN }\end{array}$} & \\
\hline
\end{tabular}

\section{SAN 4-5-6}

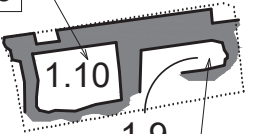

1.9

SAN 2-3

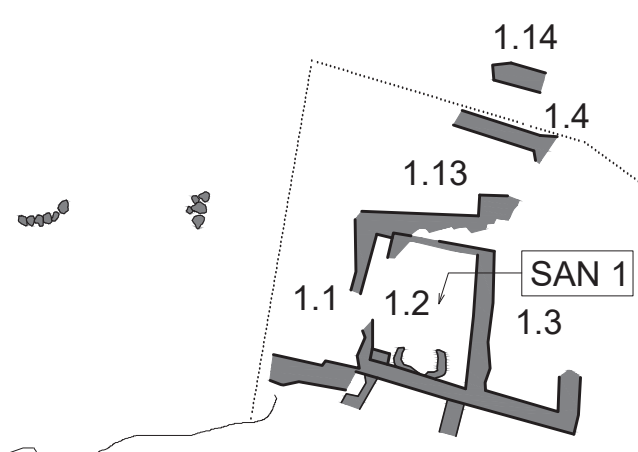

ZONE 1

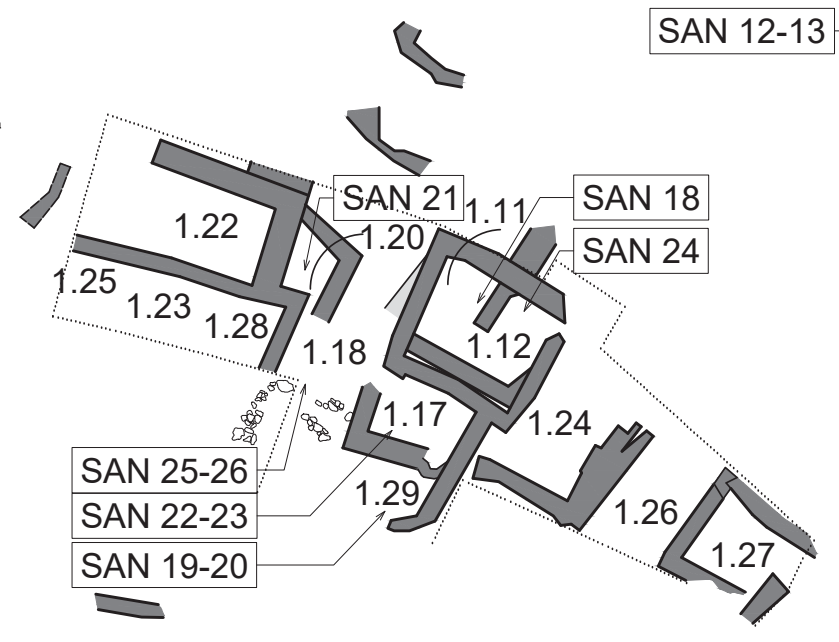

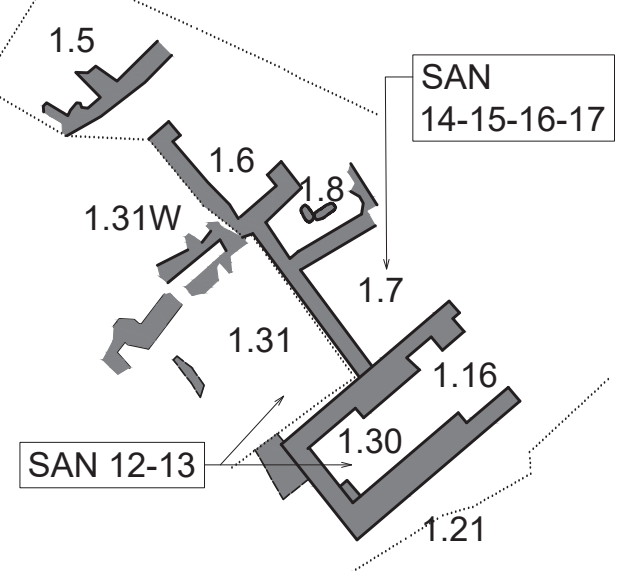

\section{ZONE 9}

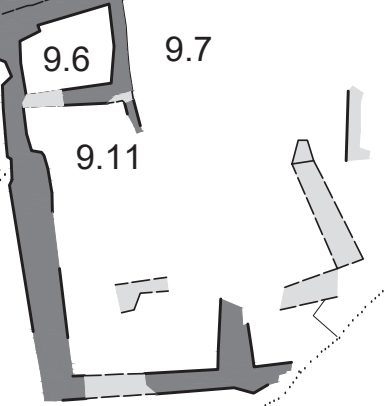




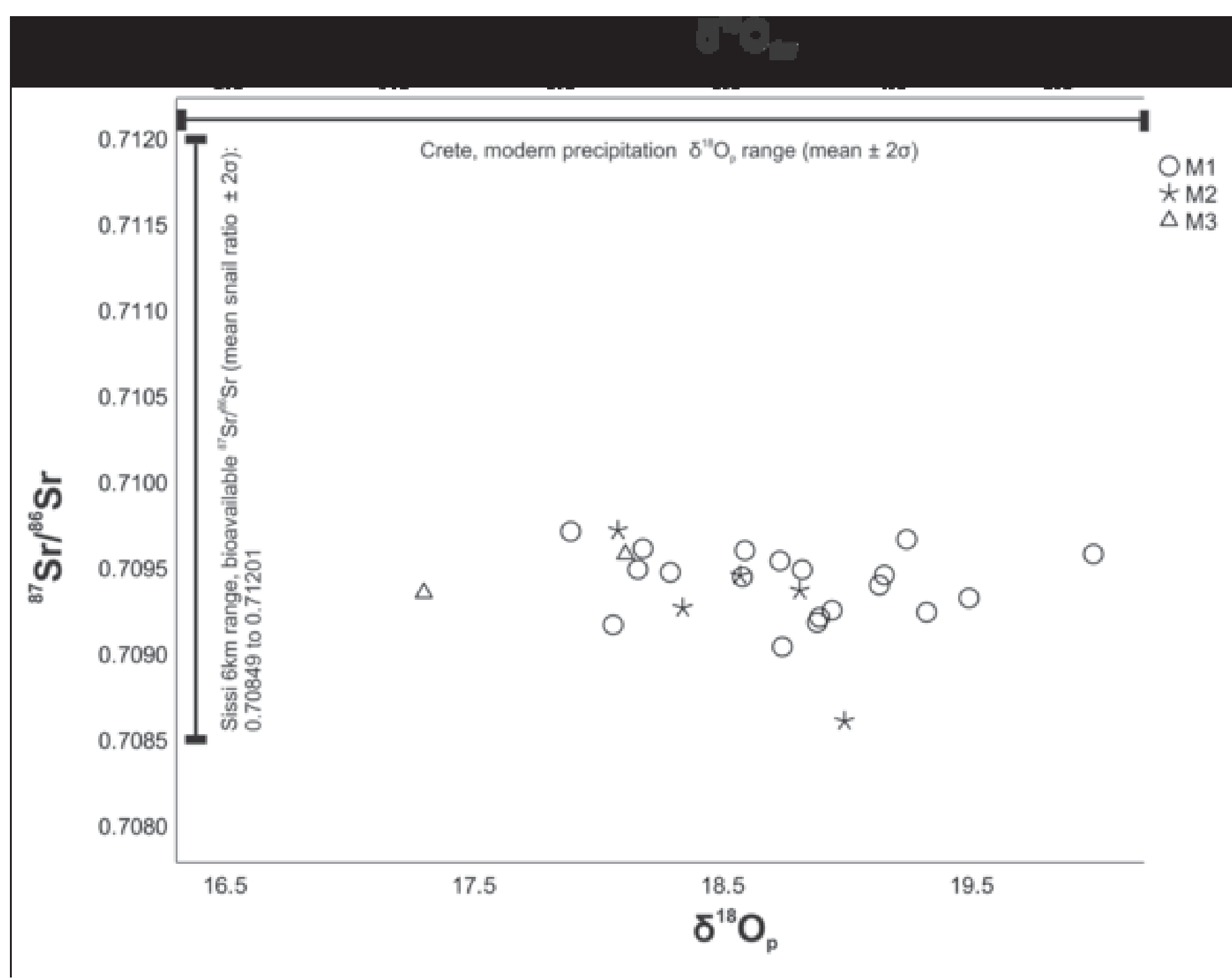




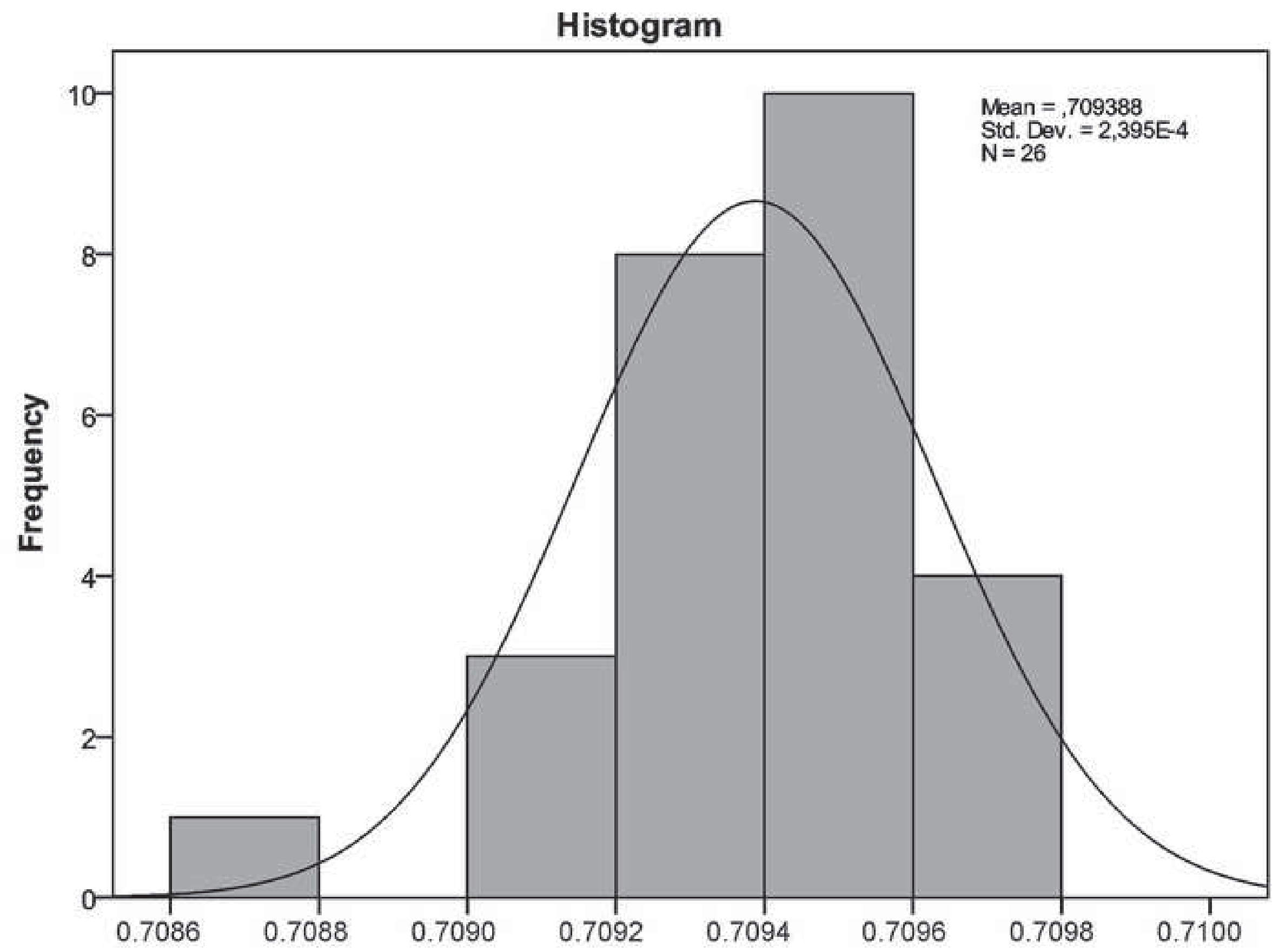




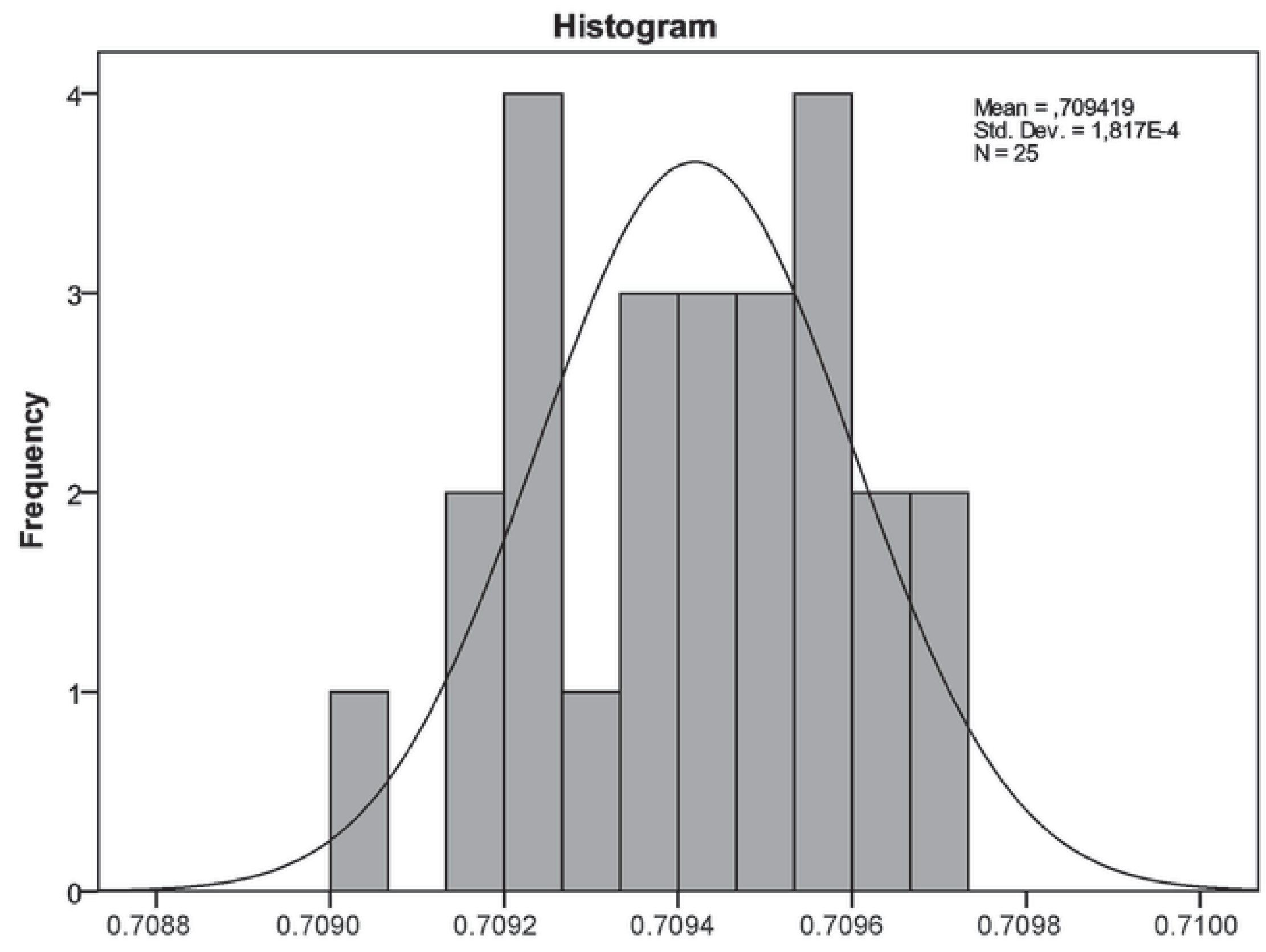




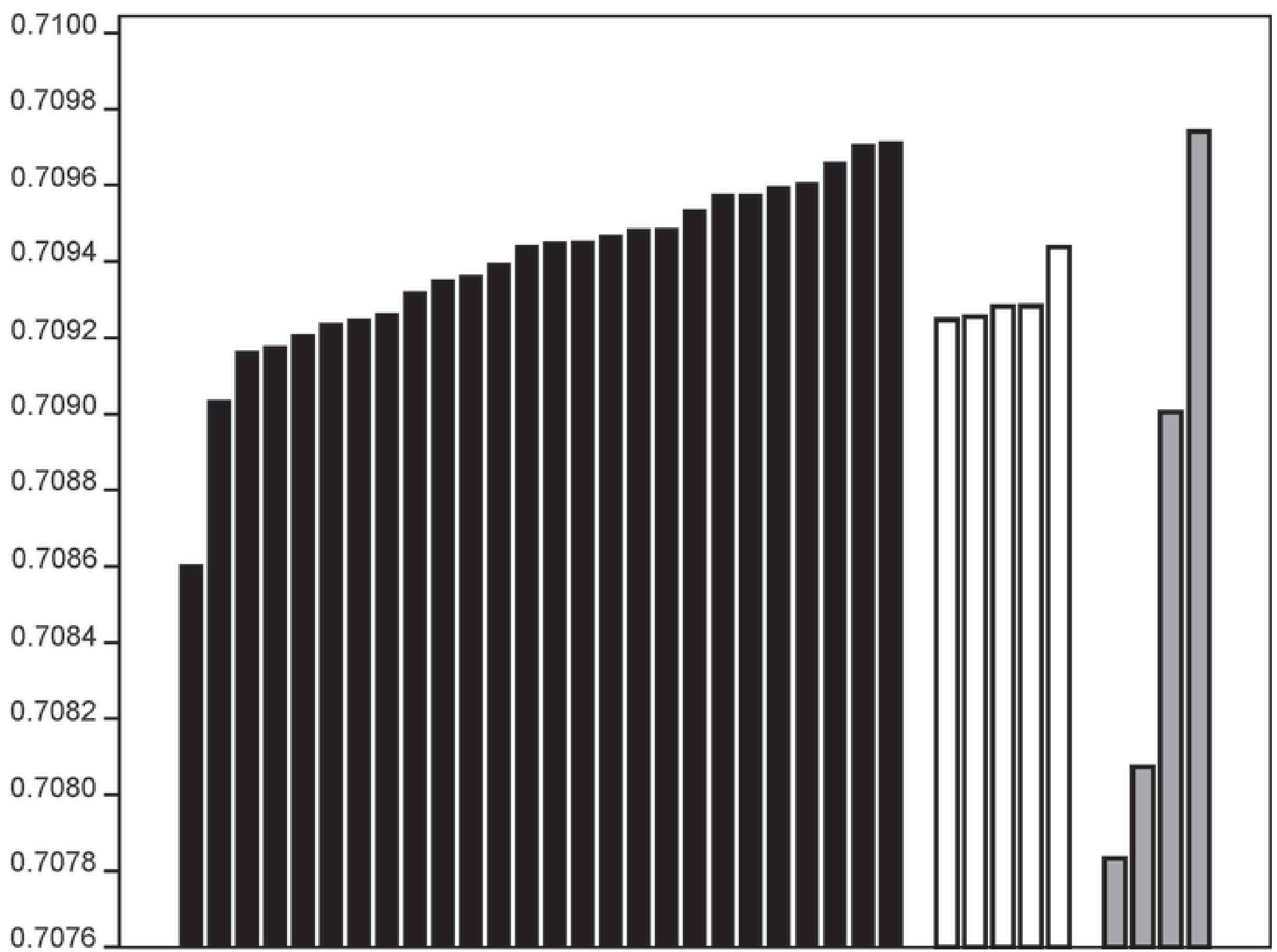




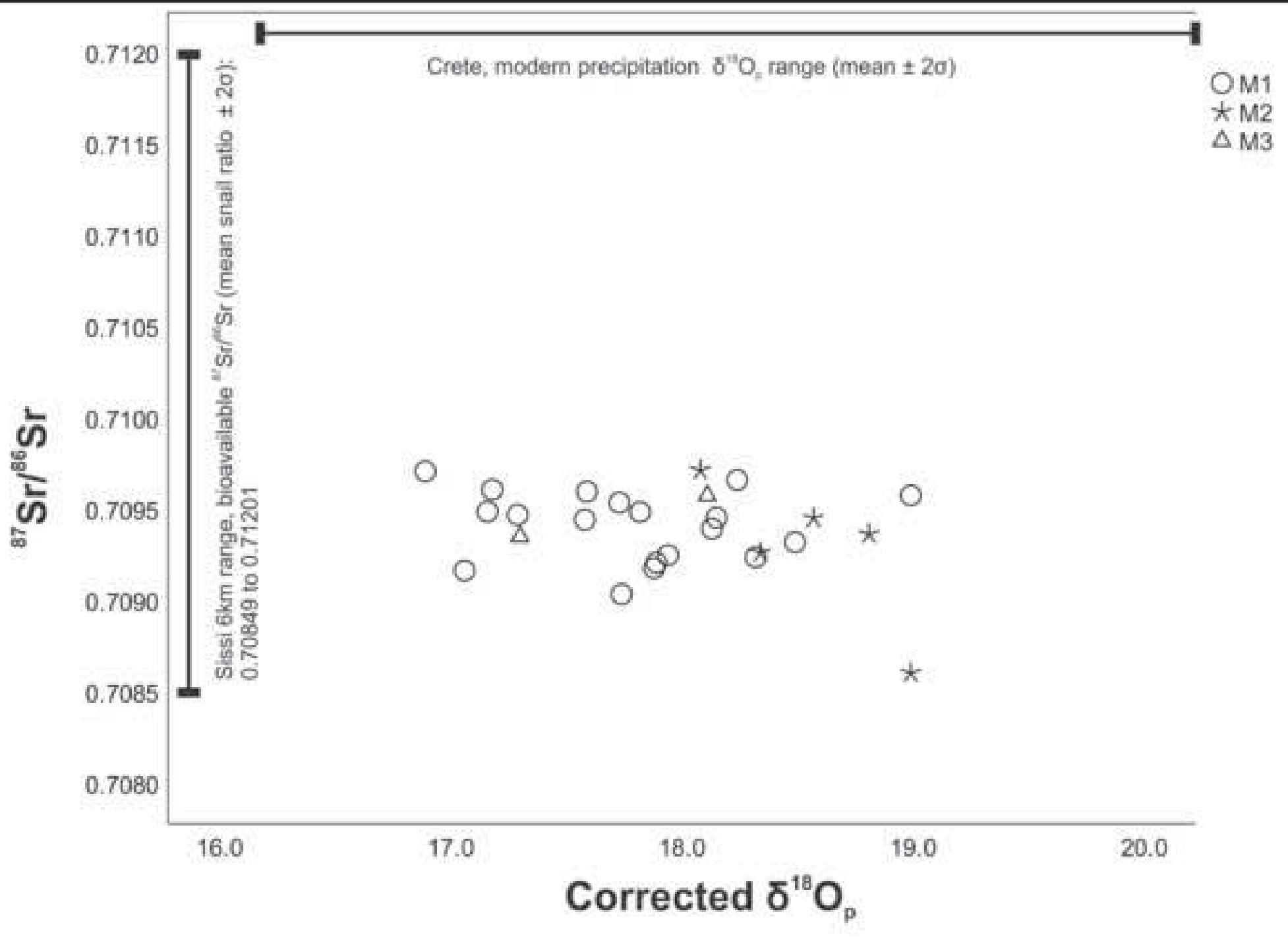


Click here to access/download

Table Table 1.docx 
Click here to access/download

Table

Table 2.docx 